Article

\title{
GPR4 Knockout Improves the Neurotoxin-Induced, Caspase-Dependent Mitochondrial Apoptosis of the Dopaminergic Neuronal Cell
}

\author{
Md Ezazul Haque ${ }^{1}{ }^{\circledR}$, Mahbuba Akther ${ }^{1}$, Shofiul Azam ${ }^{1}{ }^{(D)}$, Dong-Kug Choi ${ }^{1,2}{ }^{(D)}$ and \\ In-Su Kim 2,*(D) \\ 1 Department of Applied Life Science, Graduate School, Konkuk University, Chungju 27478, Korea; \\ mdezazulhaque@yahoo.com (M.E.H.); smritymahbuba@gmail.com (M.A.); \\ shofiul_azam@hotmail.com (S.A.); choidk@kku.ac.kr (D.-K.C.) \\ 2 Department of Biotechnology, Research Institute of Inflammatory Disease (RID), College of Biomedical and \\ Health Science, Konkuk University, Chungju 27478, Korea \\ * Correspondence: kis5497@kku.ac.kr; Tel.: +82-43-840-3905
}

Received: 11 September 2020; Accepted: 8 October 2020; Published: 12 October 2020

check for updates

\begin{abstract}
In Parkinson's disease, mitochondrial oxidative stress-mediated apoptosis is a major cause of dopaminergic neuronal loss in the substantia nigra (SN). G protein-coupled receptor 4 (GPR4), previously recognised as an orphan $\mathrm{G}$ protein coupled-receptor (GPCR), has recently been claimed as a member of the group of proton-activated GPCRs. Its activity in neuronal apoptosis, however, remains undefined. In this study, we investigated the role of GPR4 in the 1-methyl-4-phenylpyridinium ion $\left(\mathrm{MPP}^{+}\right)$and hydrogen peroxide $\left(\mathrm{H}_{2} \mathrm{O}_{2}\right)$-treated apoptotic cell death of stably GPR4-overexpressing and stably GPR4-knockout human neuroblastoma SH-SY5Y cells. In GPR4-OE cells, MPP ${ }^{+}$and $\mathrm{H}_{2} \mathrm{O}_{2}$ were found to significantly increase the expression levels of both mRNA and proteins of the pro-apoptotic Bcl-2-associated X protein (Bax) genes, while they decreased the anti-apoptotic B-cell lymphoma 2 (Bcl-2) genes. In addition, $\mathrm{MPP}^{+}$treatment activated Caspase-3, leading to the cleavage of poly (ADP-ribose) polymerase (PARP) and decreasing the mitochondrial membrane potential $(\triangle \Psi \mathrm{m})$ in GPR4-OE cells. In contrast, $\mathrm{H}_{2} \mathrm{O}_{2}$ treatment significantly increased the intracellular calcium ions $\left(\mathrm{Ca}^{2+}\right)$ and reactive oxygen species (ROS) in GPR4-OE cells. Further, chemical inhibition by NE52-QQ57, a selective antagonist of GPR4, and knockout of GPR4 by clustered regularly interspaced short palindromic repeats (CRISPR)/Cas9 decreased the Bax/Bcl-2 ratio and ROS generation, and stabilised the $\Delta \Psi \mathrm{m}$, thus protecting the SH-SY5Y cells from $\mathrm{MPP}^{+}-$or $\mathrm{H}_{2} \mathrm{O}_{2}$-induced apoptotic cell death. Moreover, the knockout of GPR4 decreased the proteolytic degradation of phosphatidylinositol biphosphate $\left(\mathrm{PIP}_{2}\right)$ and subsequent release of the endoplasmic reticulum (ER)-stored $\mathrm{Ca}^{2+}$ in the cytosol. Our results suggest that the pharmacological inhibition or genetic deletion of GPR4 improves the neurotoxin-induced caspase-dependent mitochondrial apoptotic pathway, possibly through the modulation of $\mathrm{PIP}_{2}$ degradation-mediated calcium signalling. Therefore, GPR4 presents a potential therapeutic target for neurodegenerative disorders such as Parkinson's disease.
\end{abstract}

Keywords: apoptosis; neurodegeneration; GPR4 receptor; $\mathrm{MPP}^{+}$; Parkinson's disease; CRISPR/cas9

\section{Introduction}

Parkinson's disease (PD) is a neurodegenerative disorder characterised by dopamine deficiency. An important pathological basis of PD is the loss of dopaminergic neurons due to apoptotic cell death in the substantia nigra (SN) of the brain [1]. An array of evidence suggests that reactive oxygen species (ROS)-induced oxidative stress is a major cause of the dopaminergic neuronal loss in the SN [2]. Mitochondria are key players in apoptosis during this neurodegeneration. In a cell undergoing 
apoptosis, mitochondria increase the production of oxyradicals and open the pores of its membranes, leading to the depolarisation of its transmembrane potential $(\Delta \psi \mathrm{m})$ and the release of cytochrome $\mathrm{C}[3,4]$. The B-cell lymphoma 2 (Bcl-2) family of proteins, which includes anti-apoptotic Bcl-2 and pro-apoptotic Bcl-2-associated X protein (Bax) members, plays a critical role in the initiation of the apoptotic pathway. When anti-apoptotic Bcl-2 localises in the mitochondrial inner membrane from the outer membrane, the intermembrane space protein, cytochrome $C$, is released. This binds to apoptotic peptidase activating factor 1 (APAF1) and forms a heptameric structure, known as the apoptosome. Apoptosomes recruit caspase 9 and activate a series of events, eventually activating Caspase-3 as a result [5]. Surprisingly, poly (ADP-ribose) polymerase (PARP), a nuclear protein involved in DNA repair that is specifically cleaved to a signature $89-\mathrm{kDa}$ fragment, has been implicated as an early marker for apoptotic cell death in neurons [6]. The characteristic hallmarks of the mitochondrial oxidative damage-induced apoptosis pathway can be considered to be the opening of the mitochondrial permeability transition pore (mPTP), the collapse of the mitochondrial membrane potential $(\triangle \Psi \mathrm{m})$, the release of cytochrome $C$, the activation of Caspase-3, and proteolytic degradation of PARP $[7,8]$. Surprisingly, the endoplasmic reticulum (ER) acts as a reservoir of calcium ions $\left(\mathrm{Ca}^{2+}\right)$. The ER can release $\mathrm{Ca}^{2+}$ through either its ryanodine (RYR) or inositol trisphosphate (IP3) receptors. $\mathrm{Ca}^{2+}$, once released from the ER, is taken up by the mitochondrial $\mathrm{Ca}^{2+}$ uniporter (MCU) located in the mitochondrial inner membrane [9]. An increase in mitochondrial $\mathrm{Ca}^{2+}$ is associated with an increase of the mPTP opening and ROS generation, a decrease in $\triangle \Psi \mathrm{m}$, and release of cytochrome $\mathrm{C}$, as well as excitotoxicity and apoptosis [10-12]. Recent findings suggest that an increase in the $\mathrm{Ca}^{2+}$ released from the ER can increase the mitochondrial oxidant stress of the substantia nigra pars compacta (SNc) dopaminergic (DA) neurons $[10,13]$. Alteration of the intracellular calcium homeostasis PD cybrids has also been reported [14].

1-methyl-4-phenylpyridinium ion $\left(\mathrm{MPP}^{+}\right)$and hydrogen peroxide $\left(\mathrm{H}_{2} \mathrm{O}_{2}\right)$ are the most widely employed neurotoxins, due to their ability to mimic a PD-like syndrome with apoptotic cell death through mitochondrial oxidative damage, in both cellular and animal models of PD [15-17]. $\mathrm{MPP}^{+}$, the active metabolite of 1-methyl-4-phenyl-1,2,3,6-tetrahydropyridine (MPTP), generates 5-7 times more ROS by selectively inhibiting mitochondrial complex I, thus initiating pro-apoptotic Bax/Bcl-2-dependent apoptotic cell death [15]. Besides, $\mathrm{MPP}^{+}$- and $\mathrm{H}_{2} \mathrm{O}_{2}$-mediated oxidative stress have also been reported to cause mitochondrial oxidative stress-mediated apoptotic cell death [18]. Moreover, $\mathrm{MPP}^{+}-$and $\mathrm{H}_{2} \mathrm{O}_{2}$-mediated cell death are associated with the alteration of intracellular $\mathrm{Ca}^{2+}$ homeostasis. An increase in intracellular $\mathrm{Ca}^{2+}$ due to ER stress also potentiates a decrease in $\Delta \Psi \mathrm{m}$, the release of cytochrome $C$, and the induction of apoptosis [12,19-21]. Therefore, the inhibition of pro-apoptotic signalling, or the decrease of intracellular ROS and $\mathrm{Ca}^{2+}$, may be beneficial for the protection of dopaminergic neuronal loss in PD.

$G$ protein-coupled receptor 4 (GPR4), a proton-sensing receptor, is highly sensitive to the alteration of extracellular proton concentration [22]. It belongs to a small G protein-coupled proton-sensing receptor family that includes ovarian cancer $G$ protein-coupled receptor 1 (OGR1), also referred to as GPR68, G2A, also termed GPR132, and T-cell death-associated gene 8 (TDAG8), also known as GPR65. These receptors signal through either to phosphoinositide mediated increase in intracellular $\mathrm{Ca}^{2+}$ or through modulating adenylate cyclase activity $[23,24]$. Information regarding the distribution and biology of GPR4 in the brain of an individual with PD is limited. An abundant level of GPR4 expression was observed in the retro-trapezoidal nucleus locus coeruleus, the cerebrovascular endothelium, the neurons of the dorsal raphe, and the lateral septum of a GPR4-knock-in mouse model [25]. Recently, the role of GPR4 in inflammation during ER stress pathway-mediated apoptotic cell death has been reported. In human umbilical vein endothelial cells (HUVEC) and other disease models, such as that of myocardial ischemic mice, knocking out GPR4 has been found to reduce cardiomyocyte apoptosis and improve cardiac function [26-28]. However, no study has yet to elucidate the role of GPR4 on apoptotic cell death in neurodegenerative disorders. Therefore, this work aims to forge an understanding of the role of GPR4 in neurotoxin-induced, mitochondrial oxidative stress-mediated 
apoptosis in a PD model. In particular, through our study of the overexpression and genetic deletion of GPR4, we investigate the role of GPR4 in the mitochondrial apoptosis pathway.

\section{Results}

\subsection{Expression of GPR4 Is Upregulated in Neurotoxin-Stimulated Apoptosis in SH-SY5Y Cells}

To investigate the concentrations of $\mathrm{MPP}^{+}$and $\mathrm{H}_{2} \mathrm{O}_{2}$ that precipitated a cell death of nearly $50 \%$ in the SH-SY5Y cells, $24 \mathrm{~h}$ serum-starved SH-SY5Y cells were treated with MPP $(0.25,0.5$, and $1 \mathrm{mM})$ or $\mathrm{H}_{2} \mathrm{O}_{2}(50,75$, and $125 \mu \mathrm{M})$ for $24 \mathrm{~h}$. As is shown in Figure $1 \mathrm{~A}$, when treated with the various concentrations of $\mathrm{MPP}^{+}(1 \mathrm{mM} ; 56.511 \pm 1.55 \%)$ and $\mathrm{H}_{2} \mathrm{O}_{2}(125 \mu \mathrm{M} ; 53.12 \pm 2.34 \%)$, half of the cell population in the MTT assay died. Furthermore, the mRNA and protein expressions of GPR4 in SH-SY5Y cells in both MPP ${ }^{+}-(1 \mathrm{mM})$ and $\mathrm{H}_{2} \mathrm{O}_{2}-(125 \mu \mathrm{M})$ treated serum-free media gradually increased in a time-dependent manner (3-24 h; Figure 1B).

(A).

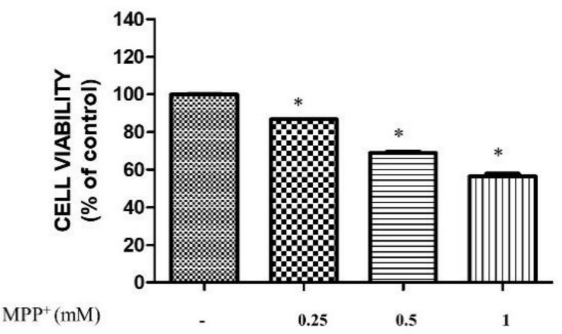

(B).

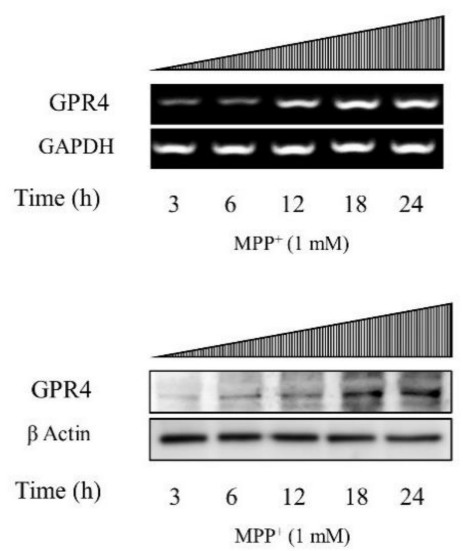

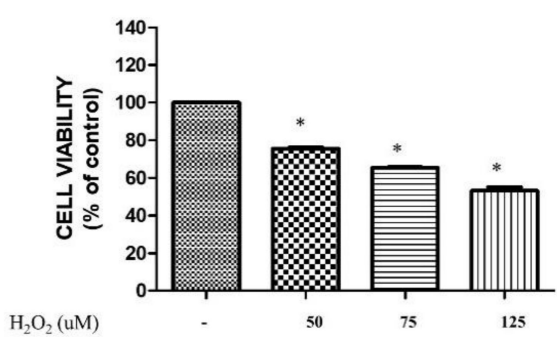
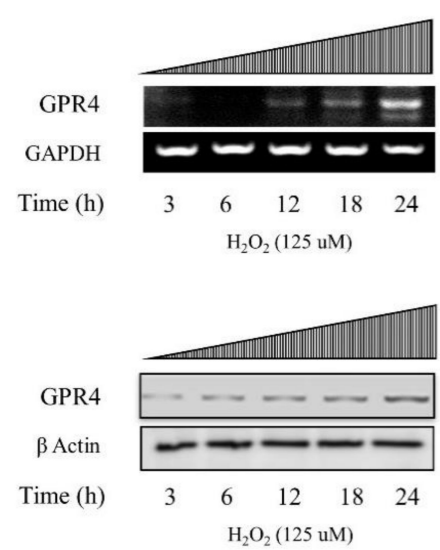

Figure 1. The cellular viability and the mRNA and protein expressions of GPR4 in $\mathrm{MPP}^{+}-$ and $\mathrm{H}_{2} \mathrm{O}_{2}$-treated SH-SY5Y cells. $24 \mathrm{~h}$ serum-starved SH-SY5Y cells were treated with different concentrations of $\mathrm{MPP}^{+}(0.25,0.5$, and $1 \mathrm{mM})$ and $\mathrm{H}_{2} \mathrm{O}_{2}(50,75$, and $125 \mu \mathrm{M})$ for $24 \mathrm{~h}$ in serum-free culture media. (A) The cellular viability of the SH-SY5Y cell after treatment with different concentrations of $\mathrm{MPP}^{+}$and $\mathrm{H}_{2} \mathrm{O}_{2}$ in serum-free media for $24 \mathrm{~h}$. (B) Reverse transcription-polymerase chain reaction (RT-PCR) and immunoblotting demonstrate the mRNA and protein expressions of GPR4 in SH-SY5Y cells at different time points $(3,6,12,18$, and $24 \mathrm{~h})$ after stimulation with $\mathrm{MPP}^{+}(1 \mathrm{mM})$ and $\mathrm{H}_{2} \mathrm{O}_{2}$ $(125 \mu \mathrm{M})$ in serum-free media. Glyceraldehyde-3-phosphate dehydrogenase (GAPDH) and $\beta$-actin were utilised as the internal controls. Mean \pm standard error of the mean (SEM; $n=3$ ) was employed to express the data. Tukey's multiple comparison test was performed using a one-way analysis of variance (ANOVA). Each ${ }^{*} p<0.05$ refers to the other sample concentrations compared with the control cells.

\subsection{Knockout of GPR4 Protects SH-SY5Y Cells from Neurotoxin-Stimulated Apoptosis in SH-SY5Y Cells}

To assess the effect of GPR4 overexpression and knockout on $\mathrm{MPP}^{+}$-induced apoptotic cell death, $24 \mathrm{~h}$ serum-starved SH-SY5Y cells were treated with $\mathrm{MPP}^{+}(1 \mathrm{mM})$ for $24 \mathrm{~h}$ in serum-free media 
(Figure 2). Following the $\mathrm{MPP}^{+}(1 \mathrm{mM})$ treatment for $24 \mathrm{~h}$ in serum-free media, the number of SH-SY5Y viable cells decreased. Furthermore, the cells became rounded, displayed an increased neurite retraction, and were found to be loosely attached to the plate. Under bright-field optics, the GPR4-OE cells treated with $\mathrm{MPP}^{+}(1 \mathrm{mM})$ exhibited less cell viability, with increased rounded cells, increased neurite retraction, and loose attachment to the surface. In contrast, the GPR4-KO cells treated with $\mathrm{MPP}^{+}(1 \mathrm{mM})$ were more viable, strongly attached, neuronal shaped, and demonstrated less neuronal retraction than both the control and the GPR4-OE cells (Figure 2A).

(A).

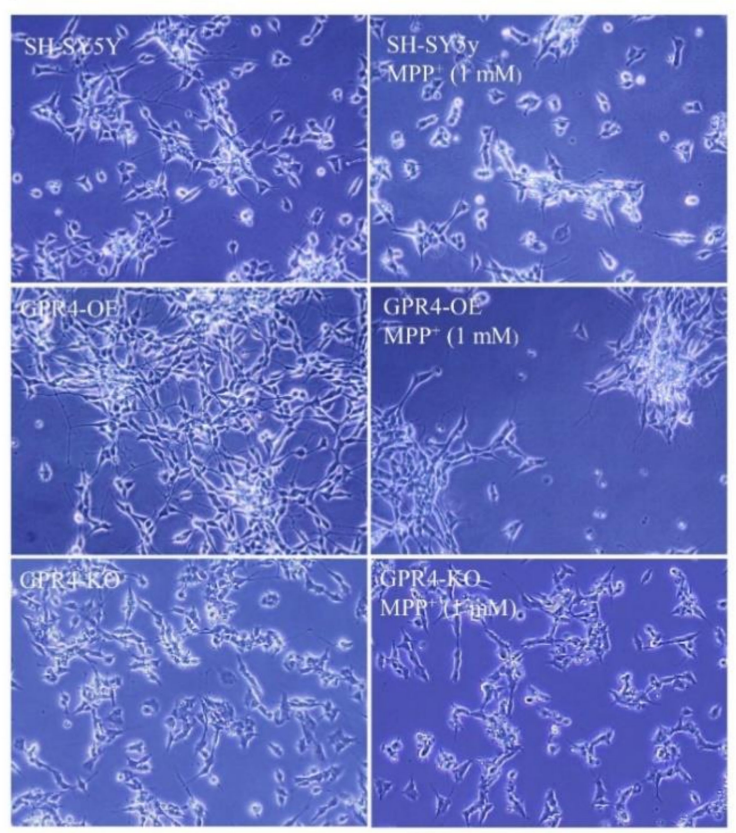

(B).

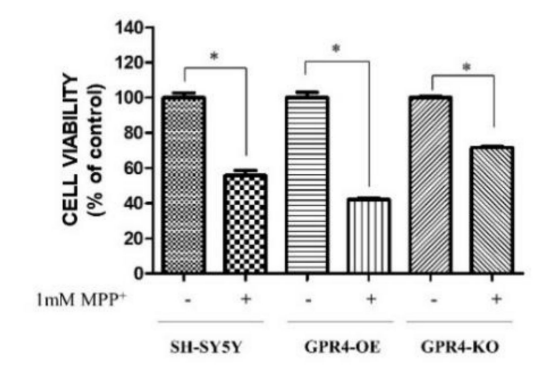

Figure 2. The cellular viability and morphology of $\mathrm{MPP}^{+}$-treated SH-SY5Y cells that were stably GPR4-overexpressing (GPR4-OE) or GPR4-knockout (GPR4-KO). $24 \mathrm{~h}$ serum-starved SH-SY5Y cells were treated with $\mathrm{MPP}^{+}(1 \mathrm{mM})$ for $24 \mathrm{~h}$ in serum-free culture media. (A) The morphology of SH-SY5Y GPR4-OE and GPR4-KO cells was observed through bright-field microscopy. (B) Cell viability was evaluated using an MTT assay. Mean \pm SEM $(n=3)$ was employed to express the data. Tukey's multiple comparison test was performed using a one-way ANOVA. Each $* p<0.05$ refers to the other sample concentrations compared with the control cells.

Cell viability was assessed with an MTT assay. The control SH-SY5Y cells presented a $55.67 \pm 5.22 \%$ cell survival rate, whereas only $42.00 \pm 2.01 \%$ of the GPR4-OE cells treated with $\mathrm{MPP}^{+}(1 \mathrm{mM})$ survived. In contrast, the $\mathrm{MPP}^{+}$-treated GPR4-KO cells had a significantly higher cell survival rate $(71.63 \pm 3.54 \%)$, at $15 \%$ higher than for the $\mathrm{MPP}^{+}$-treated control SH-SY5Y cells and almost $30 \%$ higher than for the $\mathrm{MPP}^{+}$-treated GPR4-OE cells (Figure 2B).

\subsection{Knockout of GPR4 Decreases the Bax/Bcl-2 mRNA Ratio during Neurotoxin-Induced Apoptosis in SH-SY5Y Cells}

To determine the role of GPR4 in both $\mathrm{MPP}^{+}-(1 \mathrm{mM})$ and $\mathrm{H}_{2} \mathrm{O}_{2}-(125 \mu \mathrm{M})$ stimulated apoptotic cell death, we investigated the expression levels of the Bcl-2 family proteins (Bax and $\mathrm{Bcl}-2$ ). Many studies suggest that the Bcl-2 family plays a critical role in the mitochondrial apoptotic pathway. Bax enhances the release of cytochrome $C$ from the space of the mitochondrial intermembrane to the cytosol, resulting in apoptosis. In contrast, $\mathrm{Bcl}-2$ prevents apoptosis through its prevention of cytochrome $C$ release, thereby maintaining mitochondrial cellular integrity $[29,30]$. In this study, an RT-PCR was employed to assess the mRNA expression levels of GPR4, Bax, and Bcl-2 in $24 \mathrm{~h}$ serum-starved SH-SY5Y cells treated with either $\mathrm{MPP}^{+}(1 \mathrm{mM})$ or $\mathrm{H}_{2} \mathrm{O}_{2}(125 \mu \mathrm{M}$; Figure $3 \mathrm{~A})$. 


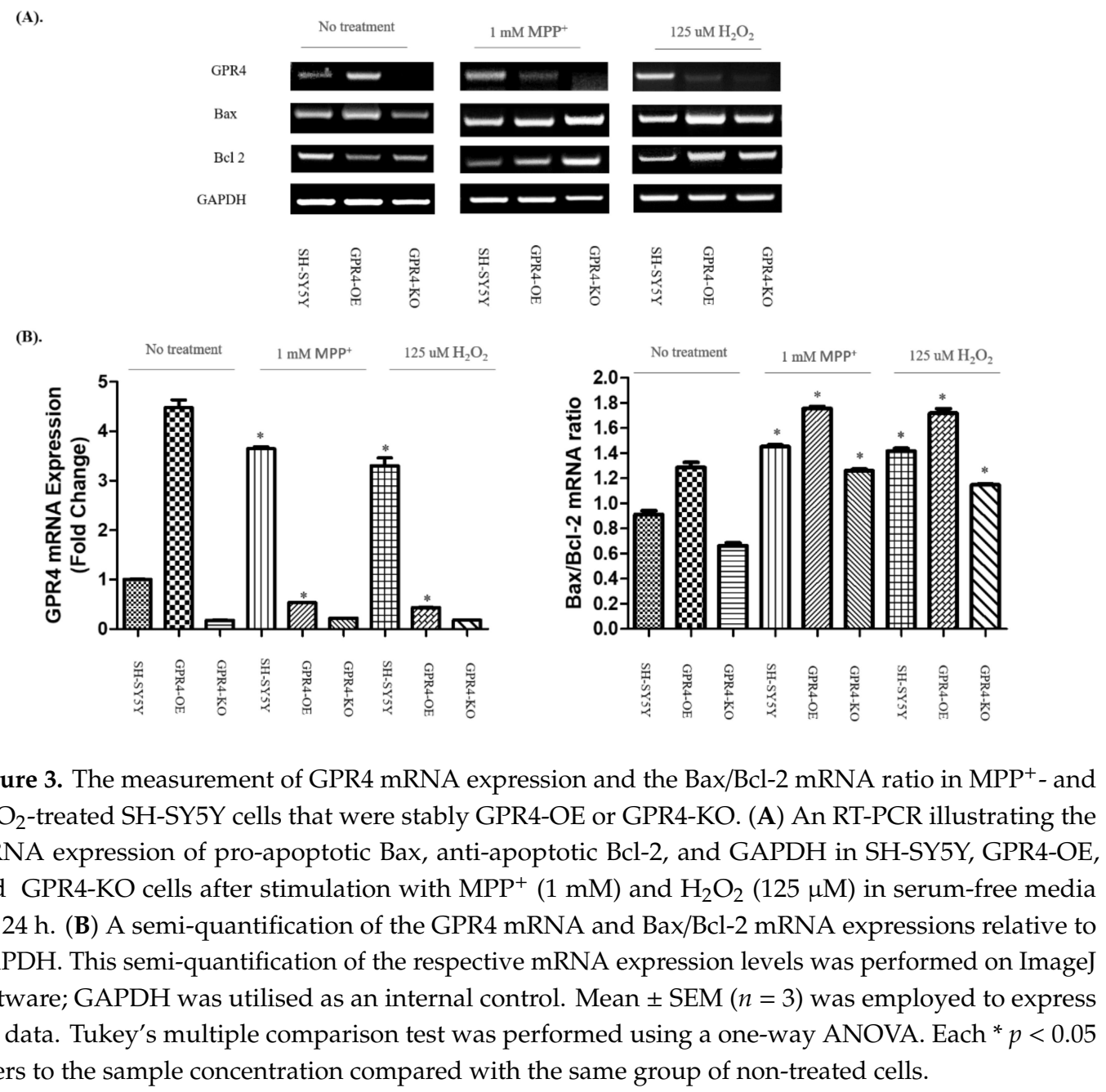

A semiquantitative analysis (Figure 3B) of the RT-PCR bands highlighted a more than 4-fold increase in the expression of GPR4 in the GPR4-OE cells without any treatment, compared with the non-treated SH-SY5Y cells. In comparison with the non-treated SH-SY5Y cells, neurotoxins increased the expression of GPR4 in the GPR4-OE cells by 3-4-fold $\left(\mathrm{MPP}^{+}, 3.65 \pm 0.03 ; \mathrm{H}_{2} \mathrm{O}_{2}, 3.31 \pm 0.17\right)$, whereas no significant difference in the GPR4 expression of the GPR4-OE cells ( $\mathrm{MPP}^{+}, 0.53 \pm 0.003$; $\mathrm{H}_{2} \mathrm{O}_{2}, 0.04 \pm 0.003$ ) was observed.

Interestingly, the ratio of Bax/Bcl-2 mRNA expression for non-treated GPR4-OE cells was slightly higher $(1.40 \pm 0.08)$ than that for the control SH-SY5Y cells, whereas the Bax/Bcl-2 mRNA ratio was slightly lower $(0.73 \pm 0.904)$ in the non-treated GPR4-KO group than that for the control SH-SY5Y cells. For the SHSY-5Y cells, treatment with MPP ${ }^{+}$or $\mathrm{H}_{2} \mathrm{O}_{2}$ significantly increased the ratio of $\mathrm{Bax} / \mathrm{Bcl}-2$ mRNA expression ( $\mathrm{MPP}^{+}, 1.59 \pm 0.02 ; \mathrm{H}_{2} \mathrm{O}_{2}, 1.55 \pm 0.04$ ). Yet, the ratio of Bax/Bcl-2 mRNA expression in $\mathrm{MPP}^{+}$- and $\mathrm{H}_{2} \mathrm{O}_{2}$-stimulated GPR4-OE cells was significantly higher ( $\mathrm{MPP}^{+}, 1.92 \pm 0.03$; $\left.\mathrm{H}_{2} \mathrm{O}_{2}, 1.88 \pm 0.07\right)$ than the neurotoxin-treated SH-SY5Y and non-treated GPR4-OE cells. Meanwhile, the ratio of Bax/Bcl-2 mRNA expression in both $\mathrm{MPP}^{+}$- and $\mathrm{H}_{2} \mathrm{O}_{2}$-stimulated GPR4-KO cells was significantly lower $\left(\mathrm{MPP}^{+}, 1.38 \pm 0.02 ; \mathrm{H}_{2} \mathrm{O}_{2}, 1.25 \pm 0.02\right)$ than both the neurotoxin-treated SH-SY5Y and GPR4-OE cells.

\subsection{Effect of a GPR4 Antagonist on the Cellular Morphology and GPR4 mRNA Expression of SH-SY5Y Cells}

To investigate the effect of the pharmacological inhibition of GPR4, we adopted a GPR4 antagonist, NE52-QQ57. At the physiological pH, NE 52-QQ57 has been reported to effectively block the cAMP that is released by GPR4 activation $\left(\mathrm{IC}_{50} 26.8 \mathrm{nM}\right)$ in HEK293 cells [3]. In this study, the impact of GPR4 


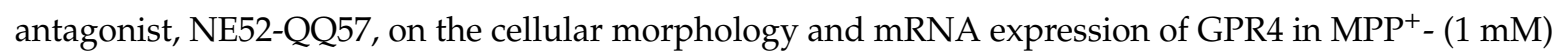
treated, $24 \mathrm{~h}$ serum-starved SH-SY5Y cells was assessed (Figure 4). The SH-SY5Y cells were treated with NE52-QQ57 $(1 \mu \mathrm{M})$ at $\mathrm{pH} 7.4$ and incubated for $24 \mathrm{~h}$ in serum-free culture media, to evaluate the effect of NE52-QQ57 on cell morphology and viability. However, no morphological alteration or cellular toxicity was observed in the control SH-SY5Y, GPR4-OE, or GPR4-KO cells (Figure 4A).

(A).

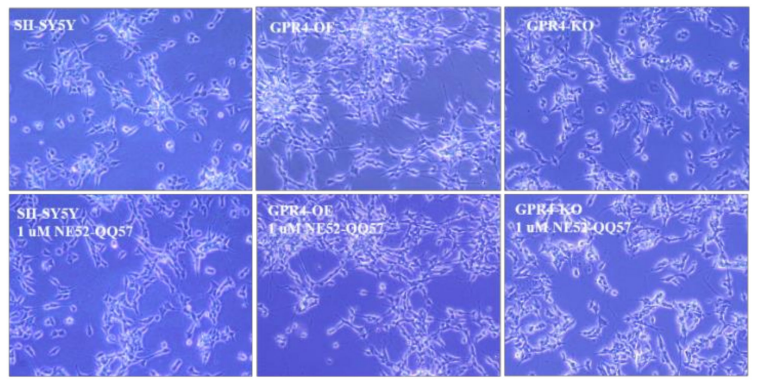

(B).

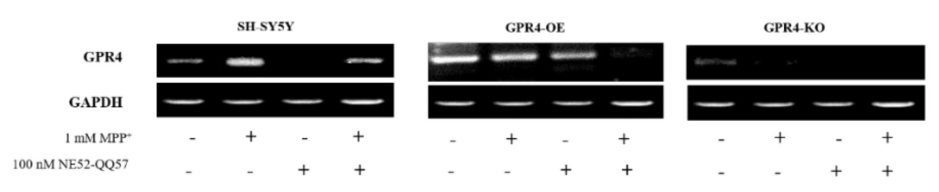

(C).

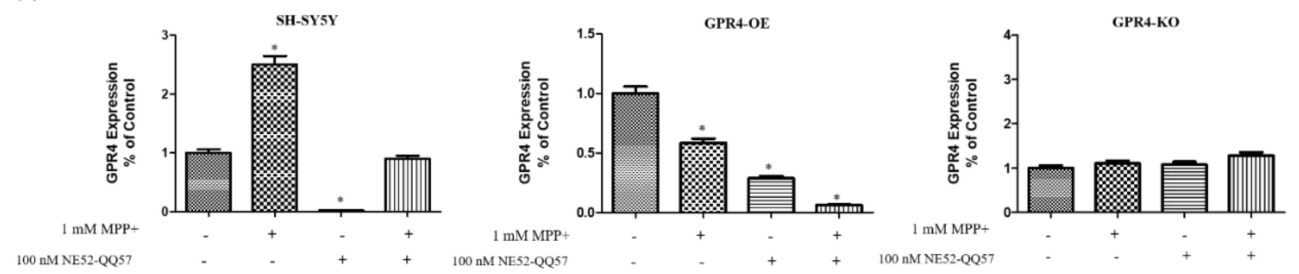

Figure 4. The effect of GPR4 antagonist, NE52-QQ57, on the cellular morphology and on GPR4 mRNA expression in $\mathrm{MPP}^{+}$-treated SH-SY5Y cells that were stably GPR4-OE or GPR4-KO. $24 \mathrm{~h}$ serum-starved SH-SY5Y cells were treated for $1 \mathrm{~h}$ with NE52-QQ57 followed by either a $24 \mathrm{~h}$ incubation or MPP ${ }^{+}$ $(1 \mathrm{mM})$ stimulation for $24 \mathrm{~h}$ in serum-free culture media. (A) The cell viability and morphology of SH-SY5Y, GPR4-OE, and GPR4-KO cells that were pre-treated for $1 \mathrm{~h}$ with NE52-QQ57. (B) An RT-PCR highlighting the mRNA expression of GPR4 and GAPDH in SH-SY5Y, GPR4-OE, and GPR4-KO cells pre-treated for $1 \mathrm{~h}$ with NE52-QQ57. (C) A semi-quantification of GPR4 mRNA expression relative to GAPDH. This semi-quantification of the respective mRNA expression levels was performed on ImageJ software; GAPDH was utilised as an internal control. Mean \pm SEM $(n=3)$ was employed to express the data. Tukey's multiple comparison test was performed using a one-way ANOVA. Each * $p<0.05$ refers to the sample concentration compared with the same group of non-treated cells.

For an RT-PCR, RNA was isolated from the cells pre-treated with NE52-QQ57 $(1 \mu \mathrm{M})$ at pH 7.4; this was incubated for an additional $24 \mathrm{~h}$ in serum-free media, with or without $\mathrm{MPP}^{+}(1 \mathrm{mM})$ stimulation. The resulting levels of GPR4 mRNA expression illustrated that the NE52-QQ5 (100 nM) had effectively blocked the expression of GPR4 on the control SH-SY5Y and the GPR4-OE cells, similar to genetically GPR4-KO cells (Figure 4B).

A semi-quantitative analysis (Figure 4C) of the RT-PCR bands demonstrated that the NE52-QQ5 significantly reduced GPR4 expression in the SH-SY5Y $(0.02 \pm 0.001$ folds $)$ and the GPR4-OE cells $(0.29 \pm 0.02$ folds), compared with the nontreated SH-SY5Y and GPR4-OE cells, respectively. Moreover, treatment with NE52-QQ5 $(100 \mathrm{nM})$ decreased GPR4 mRNA expression in the MPP $(1 \mathrm{mM})$ treated SH-SY5Y $(0.9 \pm 0.06$ folds) and GPR4-OE cells $(0.06 \pm 0.004$ folds), compared with the $\mathrm{MPP}^{+}$-stimulated SH-SY5Y and GPR4-OE cells, respectively. 
2.5. Knockout of GPR4 Decreases the Bax/Bcl-2 Protein Ratio and the Cleavage of PARP Expression in Neurotoxin-Stimulated SH-SY5Y Cells

$\mathrm{MPP}^{+}$-treated SH-SY5Y cells were assessed with immunoblotting to evaluate the effect of GPR4 antagonist, NE52-QQ57, on GPR4; the pro-apoptotic proteins, Bax and Bcl-2; and cleaved PARP expression (Figure 5). The SH-SY5Y cells were pre-treated with NE52-QQ57 (100 nM) at pH 7.4. This was followed by $24 \mathrm{~h}$ incubation, or $\mathrm{MPP}^{+}(1 \mathrm{mM})$ stimulation for $24 \mathrm{~h}$ in serum-free media.

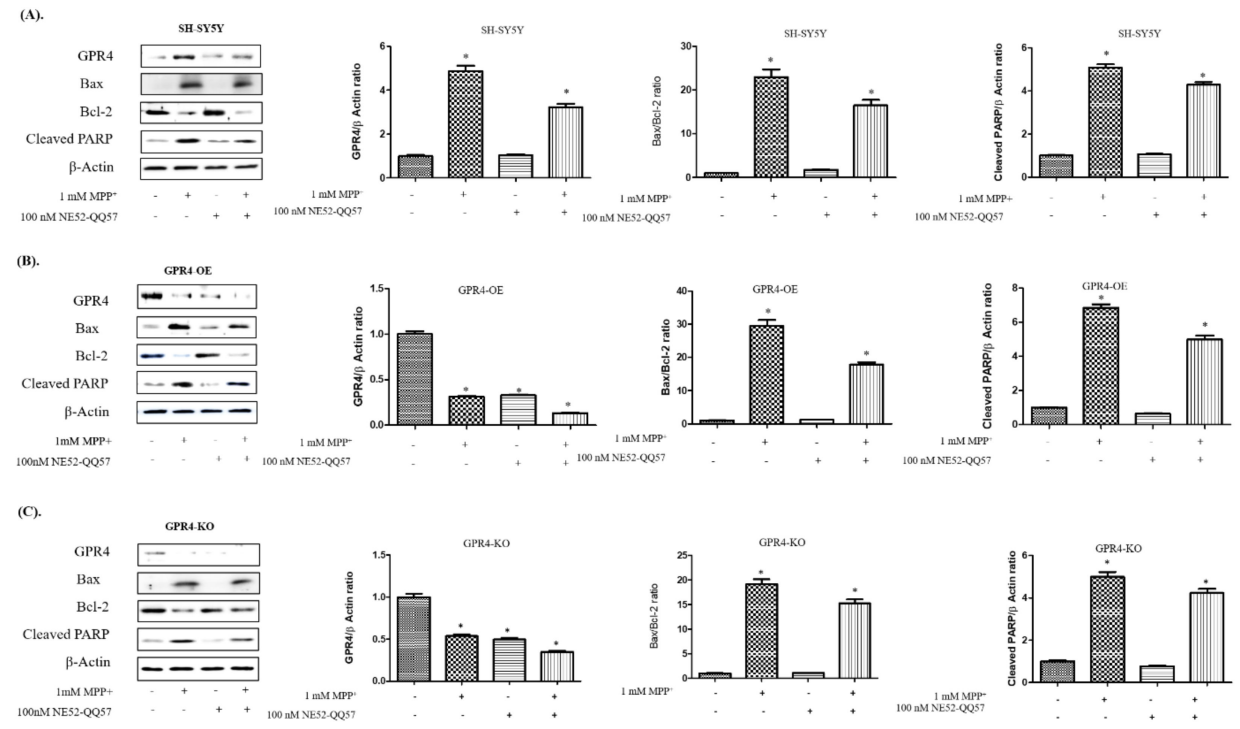

Figure 5. The effect of GPR4 antagonist, NE52-QQ57, on the GPR4 and pro-apoptotic protein expressions in $\mathrm{MPP}^{+}$-treated SH-SY5Y cells that were stably GPR4-OE or GPR4-KO. $24 \mathrm{~h}$ serum-starved SH-SY5Y cells were pre-treated for $1 \mathrm{~h}$ with NE52-QQ57 $(100 \mu \mathrm{M})$; this was followed by MPP ${ }^{+}(1 \mathrm{mM})$ stimulation for $24 \mathrm{~h}$ in serum-free culture media. (A) An immunoblot and semi-quantification of the respective protein expressions of GPR4, Bax, Bcl-2, Cleaved PARP, and $\beta$-Actin in SH-SY5Y cells. (B) An immunoblot and semi-quantification of the respective protein expressions of GPR4, Bax, Bcl-2, cleaved PARP, and $\beta$-Actin in GPR4-OE cells. (C) An immunoblot and semi-quantification of the respective protein expressions of GPR4, Bax, Bcl-2, cleaved PARP, and $\beta$-Actin in GPR4-KO cells. $\beta$-Actin was utilised as an internal control. Mean $\pm \operatorname{SEM}(n=3)$ was employed to express the data. Tukey's multiple comparison test was performed using a one-way ANOVA. Each * $p<0.05$ refers to the sample concentration compared with the same group of non-treated cells.

For the control SH-SY5Y cells, $\mathrm{MPP}^{+}$stimulation significantly increased the Bax/Bcl-2 ratio ( $22.94 \pm 2.02$ folds) and the cleaved PARP $(5.09 \pm 0.18$ folds), in comparison with the non-treated control SH-SY5Y cells. Pre-treatment with the NE52-QQ57 (100 nM) significantly lowered the GPR4 expression ( $3.21 \pm 0.18$ folds), Bax/Bcl-2 ratio (16.47 \pm 1.45 folds), and cleavage of PARP $(4.29 \pm 0.15$ folds $)$ in the $\mathrm{MPP}^{+}$-stimulated cells, in comparison with the SH-SY5Y cells that were only MPP ${ }^{+}$-treated (Figure 5A). For GPR4-OE cells, $\mathrm{MPP}^{+}$stimulation significantly increased the Bax/Bcl-2 ratio $(29.49 \pm 2.06$ folds) and the cleaved PARP $(6.85 \pm 0.23$ folds), in comparison with the non-treated GPR4-OE cells. Similar to the RT-PCR results, pre-treatment with NE52-QQ57 (100 nM) significantly lowered the GPR4 expression $(0.13 \pm 0.003$ folds), Bax/Bcl-2 ratio (17.81 \pm 0.86 folds), and cleavage of PARP ( $4.98 \pm 0.26$ folds) in the $\mathrm{MPP}^{+}$- and NE52-QQ57-treated cells, in comparison with the GPR4-OE cells that were only treated with $\mathrm{MPP}^{+}$(Figure 5B). In the GPR4-KO cells, $\mathrm{MPP}^{+}$increased the Bax/Bcl-2 ratio (19.15 \pm 1.45 folds) and cleaved PARP (4.99 \pm 0.27 folds), in comparison with non-treated GPR4-KO cells. In contrast, $\mathrm{MPP}^{+}$-stimulated GPR4-KO cells that were pre-treated with NE52-QQ57 $(100 \mathrm{nM})$ demonstrated only a minor increase in Bax/Bcl-2 ratio (15.24 \pm 0.91 folds) and cleavage of PARP ( $4.23 \pm 0.22$ folds), in comparison with GPR4-KO cells that were only $\mathrm{MPP}^{+}$-treated (Figure 5C). Overall, the GPR4-KO 
cells displayed a lesser increase in the Bax/Bcl-2 ratio (19.15 \pm 1.45 folds) and a decrease in the PARP cleavage ( $4.99 \pm 0.27$ folds), in comparison with both the MPP ${ }^{+}$-stimulated SHSY-5Y (Bax/Bcl-2, $22.94 \pm 2.02$ folds; cleaved PARP, $5.09 \pm 0.18$ folds) and GPR4-OE cells (Bax/Bcl-2, $29.49 \pm 2.06$ folds; cleaved PARP, $6.85 \pm 0.23$ folds). Thus, less apoptotic cell death was induced by $\mathrm{MPP}^{+}$.

\subsection{Knockout of GPR4 Decreases the Caspase-3 Activity and Lowers the ROS Generation in} Neurotoxin-Stimulated SH-SY5Y Cells

Caspases are important factors that trigger apoptosis. Caspase-3, in particular, is a crucial biomarker and executor of neuronal apoptosis [31]. To evaluate Caspase-3 activity, immunoblotting and a caspase activity assay were performed (Figure 6). SH-SY5Y cells were treated with MPP ${ }^{+}$ $(1 \mathrm{mM})$ for $24 \mathrm{~h}$ in serum-free media, while cell lysates were analysed through a western blot and a caspase activity assay. $\mathrm{MPP}^{+}$-treated GPR4-OE cells demonstrated a significant increase in their cleaved Caspase-3 protein levels, whereas knockout of GPR4 prevented an $\mathrm{MPP}^{+}$stimulated increase in the level of cleaved Caspase-3 (Figure 6A).

(A).

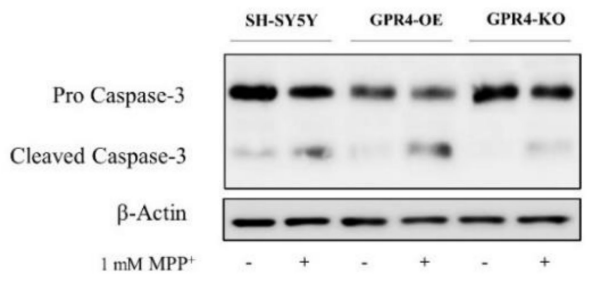

(B).

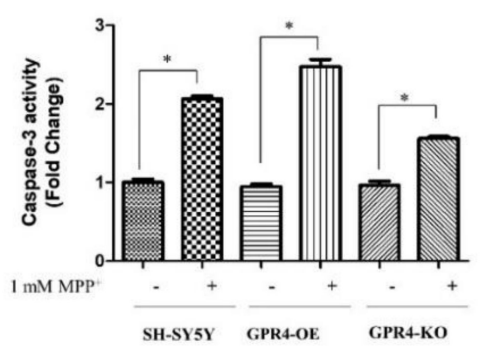

(C).

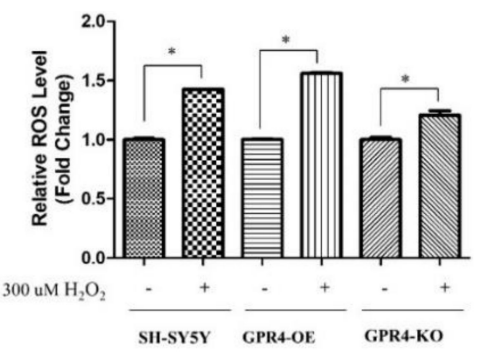

Figure 6. The Caspase- 3 activity and intracellular ROS generation in $\mathrm{MPP}^{+}$- and $\mathrm{H}_{2} \mathrm{O}_{2}$-treated SH-SY5Y cells that were stably GPR4-OE or GPR4-KO. $24 \mathrm{~h}$ serum-starved SH-SY5Y cells were treated with $\mathrm{MPP}^{+}(1 \mathrm{mM})$ for $24 \mathrm{~h}$ in serum-free culture media for an immunoblot and a caspase activity assay. SH-SY5Y, GPR4-OE, and GPR4-KO cells were treated with $\mathrm{H}_{2} \mathrm{O}_{2}(300 \mu \mathrm{M})$ for $1 \mathrm{~h}$ in serum-free culture media for a $2^{\prime}, 7^{\prime}$-dichlorofluorescein diacetate (DCFDA) assay. (A) An immunoblot of the pro caspase $\&$ cleaved Caspase- 3 and $\beta$-Actin. (B) Caspase- 3 activity was measured using a colorimetric assay kit (Sigma, CAS No. CASP-3-C) in $\mathrm{MPP}^{+}$-induced apoptotic cells. (C) The relative intracellular ROS level after $1 \mathrm{~h}$ of $\mathrm{H}_{2} \mathrm{O}_{2}(300 \mu \mathrm{M})$ treatment of $24 \mathrm{~h}$ serum-starved SH-SY5Y, GPR4-OE, and GPR4-KO cells. $\beta$-Actin was utilised as an internal control. Mean \pm SEM $(n=3)$ was employed to express the data. Tukey's multiple comparison test was performed using a one-way ANOVA. Each $* p<0.05$ refers to the sample concentration compared with the same group of non-treated cells.

The Caspase- 3 activity assay results were in complete agreement with the Caspase- 3 activity demonstrated in the immunoblot data (Figure 6B). $\mathrm{MPP}^{+}$-treated GPR4-KO cells presented a lower level of caspase activity ( $1.55 \pm 0.03$ folds $)$ than the $\mathrm{MPP}^{+}$-treated SHSY-5Y $(2.06 \pm 0.04$ folds $)$ and GPR4-OE cells ( $2.47 \pm 0.011$ folds; Figure $6 \mathrm{~B})$. 
We evaluated the effects of GPR4 overexpression and knockout on $\mathrm{H}_{2} \mathrm{O}_{2}$-induced intracellular ROS generation in SH-SY5Y cells [19]. In our study, the protective effect of the knockout of GPR4 against $\mathrm{H}_{2} \mathrm{O}_{2}$ resulted in lower intracellular ROS levels measured in the SH-SY5Y cells. DCFDA, a fluorescent dye that in the presence of ROS is oxidised to fluorescent DCF, was utilised for the detection of intracellular ROS levels. Treatment of the SH-SY5Y cells with $\mathrm{H}_{2} \mathrm{O}_{2}(300 \mu \mathrm{M})$ for $1 \mathrm{~h}$ led to a marked increase in their intracellular ROS levels. In $\mathrm{H}_{2} \mathrm{O}_{2}$-treated GPR4-OE cells, the level of intracellular ROS generation was $1.56 \pm 0.01$ folds higher than that of the non-treated GPR4-OE cells, whereas the $\mathrm{H}_{2} \mathrm{O}_{2}$-treated GPR4-KO cells demonstrated a lower level of ROS generation ( $1.20 \pm 0.04$ folds) in comparison with both the $\mathrm{H}_{2} \mathrm{O}_{2}$-treated control SH-SY5Y (1.42 \pm 0.001 folds) and the $\mathrm{H}_{2} \mathrm{O}_{2}$-treated GPR4-OE cells (1.56 \pm 0.01 folds; Figure 6B).

\subsection{Knockout of GPR4 Increases the Mitochondrial Membrane Potential (MMP) in Neurotoxin-Stimulated SH-SY5Y Cells}

Excess intracellular ROS leads to swelling of the mitochondrial matrix and rupture of the outer membrane, which opens up the mitochondrial permeability transition pores (mPTPs). As a result, the mitochondrial membrane potential (MMP) is disrupted and mitochondrial oxidative stress-mediated apoptosis is initiated [4].

In this study, to measure the MMP, $24 \mathrm{~h}$ serum-starved SH-SY5Y cells were treated with MPP ${ }^{+}$ $(1 \mathrm{mM})$ for $24 \mathrm{~h}$ in serum-free culture media. MMP was then determined through a JC-10 fluorescence quantitative assay. Similarly, in a separate experiment in a 6-well plate, cells were utilised for JC-10 fluorescence microscopy to visualise the red and green fluorescence.

Aggregated JC-10 is an indicator of MMP; the greater the ratio of red/green fluorescence, the higher the level of MMP. In a quantitative JC-10 fluorescence microplate assay, the MPP ${ }^{+}$-treated SHSY-5Y cells presented a lower red/green fluorescence ratio $(44.75 \pm 0.82 \%)$ than the untreated SH-SY5Y cells (Figure 7A). The $\mathrm{MPP}^{+}$-treated GPR4-OE cells, meanwhile, displayed the lowest red/green fluorescence ratio of all the samples $(39.44 \pm 0.39 \%)$, indicating a loss of MMP. In contrast, GPR4 knockout prevented the loss of MMP for the MPP ${ }^{+}$-treated GPR4-KO cells, as indicated by a higher red/green fluorescence ratio $(65.44 \pm 0.99 \%)$. Therefore, the $\mathrm{MPP}^{+}$-stimulated GPR4-KO cells demonstrated a higher level of MMP than either the MPP ${ }^{+}$-stimulated SH-SY5Y $(44.75 \pm 0.82 \%)$ or the GPR-OE $(39.44 \pm 0.39 \%)$ cells.

In this study, the aggregated JC-10 created red fluorescence in the polarised mitochondrial membrane. When the MMP collapsed in apoptotic cells, the JC-10 retained its monomeric form, which is characterised by green fluorescence. An increase in the red/green fluorescence intensity ratio indicated intact mitochondria. In a separate experiment, to visualise the JC-10 fluorescence dye in the $\mathrm{MPP}^{+}$-treated cells, JC-10 fluorescence microscopy was employed. In the control SHSY-5Y cells, both red and green fluorescence was observed, with a high level of red fluorescence and low level of green fluorescence. In contrast, the level of green fluorescence was higher and the red fluorescence remarkably lower in both the $\mathrm{MPP}^{+}$-treated SHSY-5Y and GPR4-OE cells, when compared with the control SHSY-5Y cells. In the $\mathrm{MPP}^{+}$-treated GPR4-KO cells, the red fluorescence was restored close to that of the control SHSY-5Y cells, while the level of green fluorescence was decreased (Figure 7B). These results suggest that GPR4 knockout restores the $\mathrm{MPP}^{+}$-induced a loss of MMP in dopaminergic neurons.

\subsection{Knockout of GPR4 Decreases the Intracellular Calcium in Neurotoxin-Stimulated SH-SY5Y Cells}

Increases in intracellular $\mathrm{Ca}^{2+}$ in association with $\mathrm{MPP}^{+}-$or $\mathrm{H}_{2} \mathrm{O}_{2}$-mediated apoptotic cell death have been previously reported [32]. Several studies have suggested that an increase in the intracellular $\mathrm{Ca}^{2+}$ released from the ER store by the inositol trisphosphate receptor $\left(\mathrm{IP}_{3} \mathrm{R}\right)$ is directly responsible for mitochondrial $\mathrm{Ca}^{2+}$ overload [33,34]. However, the exact mechanism by which $\mathrm{MPP}^{+}$or $\mathrm{H}_{2} \mathrm{O}_{2}$ stimulation increases the intracellular calcium is not clearly understood. Interestingly, several studies have demonstrated that $\mathrm{H}_{2} \mathrm{O}_{2}-/ \mathrm{MPP}^{+}$-mediated mitochondrial oxidative stress is associated with an intracellular $\mathrm{Ca}^{2+}$ spike, which increases the $\mathrm{Bax} / \mathrm{Bcl}-2$ ratio, the release of cytochrome C, mitochondrial depolarisation, and the Caspase-3 activity in neuronal cells [19,32]. 
Previous reports have suggested that many G protein coupled-receptors (GPCRs), such as GPR4, which releases $G_{\beta \gamma}$ and activates $G_{i}$, are capable of $\mathrm{Ca}^{2+}$ signalling. Few GPCRs, however, harness $\mathrm{G}_{\beta \gamma}$-dependent activation of $\mathrm{PLC}_{\beta}$ to release ER-stored $\mathrm{Ca}^{2+}$ into the cytoplasm through $\mathrm{PIP}_{2}$ degradation $[35,36]$. In this study, the $\mathrm{MPP}^{+}$-treated GPR4-OE cells demonstrated an increased proteolytic degradation of $\mathrm{PIP}_{2}$, in comparison with the SH-SY5Y cells treated with $\mathrm{MPP}^{+}$. Contrastingly, the $\mathrm{MPP}^{+}$-stimulated GPR4-KO cells presented a particularly low degradation of $\mathrm{PIP}_{2}$ compared with both the $\mathrm{MPP}^{+}$-stimulated SH-SY5Y and GPR4-OE cells (Figure 8A).

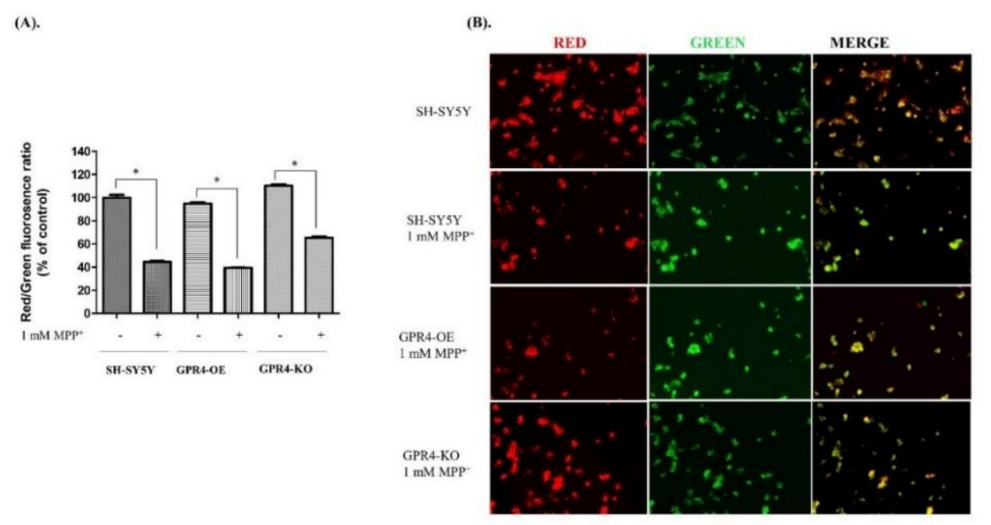

Figure 7. The measurement of mitochondrial membrane potential (MMP) in $\mathrm{MPP}^{+}$-treated SH-SY5Y cells that were stably GPR4-OE or GPR4-GPR4-KO. $24 \mathrm{~h}$ serum-starved SH-SY5Y cells were treated with $\mathrm{MPP}^{+}(1 \mathrm{mM})$ for $24 \mathrm{~h}$ in serum-free culture media; a JC-10 fluorescence quantitative assay (according to the manufacturer's instructions) and fluorescence microscopy were then employed to measure their MMP. (A) The percentage ratios of J-aggregates (red) and J-monomers (green). (B) MMP changes were monitored with a JC-10 dye that is detectable through fluorescence microscopy. Mean \pm SEM $(n=3)$ was employed to express the data. Tukey's multiple comparison test was performed using a one-way ANOVA. Each * $p<0.05$ refers to the sample concentration compared with the same group of non-treated cells.

To evaluate whether GPR4 overexpression increased intracellular calcium through $\mathrm{G}_{\beta \gamma}$ modulation of the $\mathrm{PLC}_{\beta}-\mathrm{PIP}_{2}$ pathway, SH-SY5Y cells were treated with $\mathrm{MPP}^{+}(1 \mathrm{mM})$ for $24 \mathrm{~h}$ in serum-free media. Cell lysates were analysed through western blotting to determine the degradation of PIP 2 . The SH-SY5Y cells were treated with $\mathrm{H}_{2} \mathrm{O}_{2}(200 \mu \mathrm{M})$ for $2 \mathrm{~h} 30$ min to determine their relative intracellular $\mathrm{Ca}^{2+}$, utilising a Fluo-4 AM calcium indicator in a fluorescence microplate assay. Similarly, in a separate 6-well plate, cells stained with a Fluo-4 AM calcium indicator were observed under a fluorescence microscope.

The quantitative analysis of intracellular $\mathrm{Ca}^{2+}$, as indicated by the Fluo-4 AM microplate assay, found levels of intracellular $\mathrm{Ca}^{2+}$ for the $\mathrm{H}_{2} \mathrm{O}_{2}$-treated GPR4-OE cells that were $369.58 \pm 24.75 \%$ higher than those for the non-treated GPR4-OE cells. In contrast, the $\mathrm{H}_{2} \mathrm{O}_{2}$-treated GPR4-KO cells presented significantly lower levels of intracellular $\mathrm{Ca}^{2+}(181.28 \pm 0.85 \%)$, in comparison with the $\mathrm{H}_{2} \mathrm{O}_{2}$-treated SH-SY5Y (243.25 $\pm 7.81 \%$ ) and $\mathrm{H}_{2} \mathrm{O}_{2}$-treated GPR4-OE cells (369.58 $\pm 24.75 \%$; Figure 8B).

In a separate experiment to visualise intracellular $\mathrm{Ca}^{2+}$ levels in the $\mathrm{H}_{2} \mathrm{O}_{2}$-treated cells, Fluo-4 AM fluorescence microscopy was employed. This round of microscopy demonstrated similar results to those obtained from the quantitative microplate assay. $\mathrm{H}_{2} \mathrm{O}_{2}$-treated GPR4-OE cells displayed the highest levels of green Fluo-4 AM fluorescence, while $\mathrm{H}_{2} \mathrm{O}_{2}$-treated GPR4-KO cells produced lower levels of green Fluo-4 AM fluorescence than both the $\mathrm{H}_{2} \mathrm{O}_{2}$-treated SH-SY5Y and GPR4-KO cells (Figure 8C). Overall, these data suggest that the increase in intracellular calcium associated with $\mathrm{H}_{2} \mathrm{O}_{2}$ - or $\mathrm{MPP}^{+}$-mediated mitochondrial oxidative stress is exaggerated by GPR4 overexpression, whereas GPR4 knockout prevents an increase in intracellular $\mathrm{Ca}^{2+}$ through the decrease of $\mathrm{PIP}_{2}$ degradation, and thus restricts the release of $\mathrm{Ca}^{2+}$ from the ER by preventing the degradation of 
$\mathrm{PIP}_{2}$. Therefore, GPR4-PLC ${ }_{\beta}-\mathrm{PIP}_{2}$ signalling may act as a key factor through which GPR4 increases intracellular calcium and potentiates mitochondrial oxidative stress-mediated apoptosis.

(A).

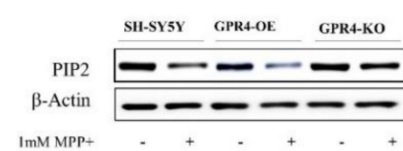

(B).

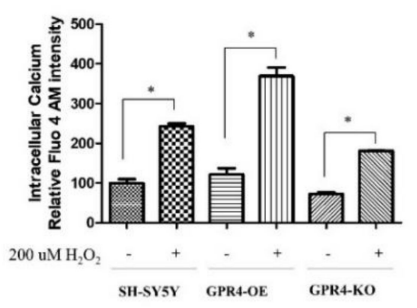

(C).

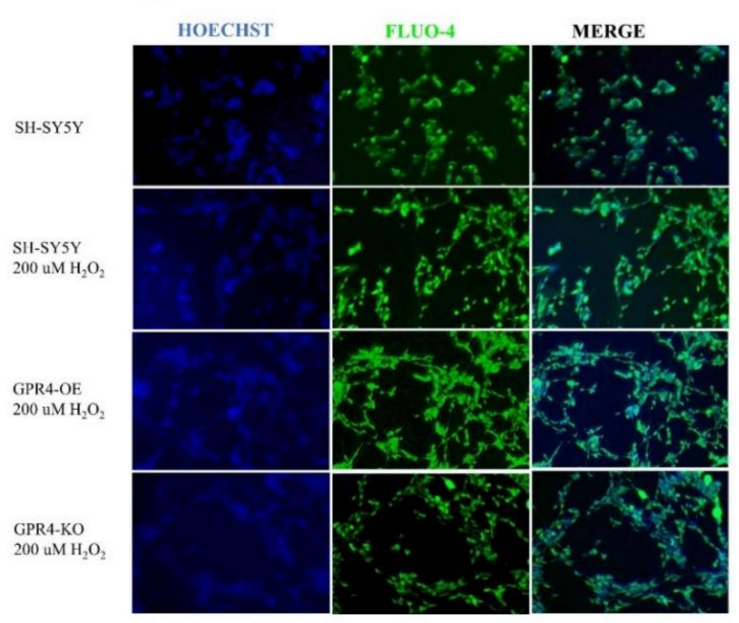

Figure 8. Phosphatidylinositol biphosphate $\left(\mathrm{PIP}_{2}\right)$ calcium signalling and intracellular calcium levels in $\mathrm{MPP}^{+}$-treated SH-SY5Y cells that were stably GPR4-OE or GPR4-KO. $24 \mathrm{~h}$ serum-starved SH-SY5Y cells were treated with $\mathrm{MPP}^{+}(1 \mathrm{mM})$ for $24 \mathrm{~h}$ in serum-free culture media for the purpose of immunoblotting. The SH-SY5Y cells were then treated with $\mathrm{H}_{2} \mathrm{O}_{2}(200 \mu \mathrm{M})$ for $2 \mathrm{~h} 30 \mathrm{~min}$ in serum-free culture media and subjected to a Fluo-4 AM fluorescence assay and fluorescence microscopy. Detection of the Fluo-4 AM fluorescence intensity and related imaging were carried out according to the manufacturer's instructions. Cells were counter-stained with Hoechst dye. (A) An immunoblot of the PIP 2 and $\beta$-Actin. (B) A quantitative analysis of the Fluo-4 AM fluorescence intensity in $\mathrm{H}_{2} \mathrm{O}_{2}-(200 \mu \mathrm{M})$ treated cells. (C) Fluo-4 AM calcium imaging of the intracellular calcium level. Mean $\pm \operatorname{SEM}(n=3)$ was employed to express the data. Tukey's multiple comparison test was performed using a one-way ANOVA. Each * $p<0.05$ refers to the sample concentration compared with the same group of non-treated cells.

\section{Discussion}

In this study, we investigated the roles of GPR4 overexpression, pharmacological inhibition, and genetic knockout in the mitochondrial oxidative stress-induced apoptotic cell death that is associated with PD. Although many studies have reported the activation of GPR4 at the physiological $\mathrm{pH}$ range (7.0-7.4), overexpression of GPR4 showed relatively high GPR4 activity at neutral pH 7.4 [37]. In transiently GPR4-overexpressing HEK293 cells, GPR4 is inactive at pHs higher than 8.0, whereas it is highly active at the physiological $\mathrm{pH}, 7.4$, and substantially less active at $\mathrm{pHs}$ down to 6.8 (plausible in the range of physiological acidification) [38]. The $\mathrm{pH}$ sensitivity of GPR4 has been reported to vary for different cells, though potentially due to the methods employed in different laboratories [25]. In the natively GPR4-expressing cell, HUVEC, pHs from 7.4 to 7.0 have been shown to result in a 1.5-fold activation of GPR4 [25]. In this study, we found an increase in GPR4 mRNA expression at pH 7.4 in both SH-SY5Y and stably GPR4-OE cells in serum-starved media (data not added). A very slight increase in the expression of GPR4 was observed at $\mathrm{pH}$ 6.4. Therefore, to maintain consistency, we conducted all the experiments at a $\mathrm{pH} \sim 7.4$. This was also the $\mathrm{pH}$ of the culture media that we employed.

Human-derived neuroblastoma SH-SY5Y cells are widely used in neuroscientific research as an in vitro model for the investigation of neuronal differentiation and neuroprotective events. Stimulation with several neurotoxins, such as MPP ${ }^{+}$, MPTP, rotenone, 6-OHDA, and $\mathrm{H}_{2} \mathrm{O}_{2}$, has been utilised to induce oxidative stress-mediated apoptotic death, thereby mimicking neurodegenerative diseases, including PD and aging [39-41]. To determine the final concentration of $\mathrm{H}_{2} \mathrm{O}_{2}$ and MPP ${ }^{+}$, SH-SY5Y cells were treated with $\mathrm{H}_{2} \mathrm{O}_{2}$ at different concentrations, ranging from $75 \mu \mathrm{M}$ to $125 \mu \mathrm{M}$, for $24 \mathrm{~h}$, as well 
as with $\mathrm{MPP}^{+}$, ranging from $250 \mu \mathrm{M}$ to $1 \mathrm{mM} . \mathrm{H}_{2} \mathrm{O}_{2}$ and $\mathrm{MPP}^{+}$both decreased the cell viability in a concentration-dependent manner, with optimum cytotoxicity being observed at concentrations of $125 \mu \mathrm{M}$ for $\mathrm{H}_{2} \mathrm{O}_{2}$ and $1 \mathrm{mM}$ for $\mathrm{MPP}^{+}$; these concentrations were selected for further experiments to determine their cytotoxicity in the serum-free SH-SY5Y cell line. In our study, GPR4 mRNA and protein expressions were increased in a time-dependent manner for $24 \mathrm{~h}$ in both $\mathrm{MPP}^{+}$- and $\mathrm{H}_{2} \mathrm{O}_{2}$-treated SH-SY5Y cells. Hence, GPR4 is directly linked with $\mathrm{MPP}^{+}$- and $\mathrm{H}_{2} \mathrm{O}_{2}$-induced apoptotic cell death.

Both the pro-apoptotic protein, Bax, and the anti-apoptotic protein, $\mathrm{Bcl}-2$, are members of the Bcl-2 family and are directly involved in apoptotic cell death. The balance between these two proteins of the Bcl-2 family, or an increase in the Bax/Bcl-2 ratio, indicates the early phases of an apoptotic cascade $[29,30]$. Significant increases in ROS, or the Bax/Bcl-2 ratio, result in the collapse of the mitochondrial membrane potential, the release of cytochrome $\mathrm{C}$, the activation of Caspase-3, the cleavage of PARP, and, subsequently, apoptotic cell death [6,7]. Both $\mathrm{MPP}^{+}$- and $\mathrm{H}_{2} \mathrm{O}_{2}$-induced apoptotic cell deaths bear the characteristic hallmarks of an increase in the $\mathrm{Bax} / \mathrm{Bcl}-2$ ratio, the release of cytochrome-C, and the activation of the proteolytic enzyme, Caspase-3, which cleaves PARP and induces apoptotic cell death [7,8]. In our study, the overexpression of GPR4 in SH-SY5Y cells significantly increased the effect of either $\mathrm{MPP}^{+}$or $\mathrm{H}_{2} \mathrm{O}_{2}$ and increased the $\mathrm{Bax} / \mathrm{Bcl}-2$ ratio, as was seen in both the immunoblot and RT-PCR. As a result, this significantly increased the protein level of the cleaved Caspase-3, the Caspase-3 mediated cleavage of PARP, and the Caspase- 3 activity. On the contrary, the CRISPR/Cas9 knockout of GPR4 was found to result in a lesser increase in the Bax/Bcl-2 mRNA and protein ratio in both $\mathrm{MPP}^{+}$- and $\mathrm{H}_{2} \mathrm{O}_{2}$-treated cells. Knockout of GPR4 was also shown to reduce the cleavage of PARP after $\mathrm{MPP}^{+}$treatment. NE52-QQ57, a selective antagonist of GPR4, demonstrated a similar level of the inhibition of GPR4 expression, as was determined through both our immunoblots and RT-PCR.

We further investigated the effect of GPR4 on mitochondrial oxidative stress-induced increases in intracellular ROS generation and MMP. Surprisingly, GPR4-OE was found to significantly increase tricellular ROS generation in SH-SY5Y cells, whereas GPR4-KO generated a lower level of intracellular ROS accumulation, after a high concentration of $\mathrm{H}_{2} \mathrm{O}_{2}$ treatment. Similarly, through both a JC-10 assay and fluorescence microscopy, the knockout of GPR4 was found to decrease mitochondrial membrane depolarisation. In JC-10-tagged fluorescence microscopy, knockout of GPR4 was seen to prevent MPP ${ }^{+}$ stimulated decrease red fluorescence and increase green fluorescence. The latter was highly increased in the case of GPR4-OE as membrane depolarisation occurs $24 \mathrm{~h}$ after $\mathrm{MPP}^{+}$treatment.

Besides mitochondrial dysfunction, abnormal protein aggregation and dysregulated $\mathrm{Ca}^{2+}$ homeostasis are other factors that may be involved in the neurodegeneration observed in individuals with PD [42]. Recent findings suggest that increases in cytosolic $\mathrm{Ca}^{2+}$ occur at both early and late stages of the apoptotic pathway. In both cases, $\mathrm{ER} \mathrm{Ca}^{2+}$ channels are linked with the release of $\mathrm{Ca}^{2+}$ to the cytoplasm $[33,34]$. However, the exact mechanism by which intracellular $\mathrm{Ca}^{2+}$ modulates mitochondrial oxidative stress-mediated apoptosis remains elusive. Many studies have suggested that $\mathrm{MPP}^{+}$- and $\mathrm{H}_{2} \mathrm{O}_{2}$-induced apoptosis are associated with an increase in intracellular calcium levels [43]. For example, Sing et al. (2016) demonstrated that the administration of Nimodipine, an L-type calcium channel blocker, protected from MPTP-induced dopaminergic neuronal death in an animal model of PD. More importantly, providing evidence for Nimodipine as a means to improve mitochondrial integrity and function. In the study, Nimodipine attenuated the MPTP-induced loss of tyrosine hydroxylase-positive dopaminergic neurons in the SN. It also improved mitochondrial oxygen consumption and inhibited ROS production, as well as improving mitochondrial integrity and function in striatal mitochondria [43]. These findings provide evidence in support of the notion that calcium signalling is linked with neurotoxin-induced mitochondrial dysfunction and neurodegeneration. GPR4 is a $\mathrm{G}_{\mathrm{s}}$-coupled receptor that signals through adenylate cyclase and also via $G$ proteins $G_{13}$ and $G_{q / 11}$. GPR4 is well known for its ability to recognise phospholipase $C \beta\left(\right.$ PLC $\left._{\beta}\right)$ as its canonical target [44]. $\mathrm{G}_{\mathrm{q}}$ class $\alpha$ subunits, or $\mathrm{G}_{\beta \gamma}$ released by GPCR, activate $\mathrm{Ca}^{2+}$ signalling through $\mathrm{G}_{\beta \gamma}$-dependent activation of $\mathrm{PLC}_{\beta}$. Upon activation, $\mathrm{PLC}_{\beta}$ hydrolyses $\mathrm{PIP}_{2}$ to generate $\mathrm{IP}_{3} . \mathrm{IP}_{3}$ binds 
to the ER-resident $\mathrm{IP}_{3}$ receptors, which act as $\mathrm{Ca}^{2+}$ release channels to release ER-stored $\mathrm{Ca}^{2+}$ into the cytoplasm [35]. In this study, overexpression of GPR4 significantly increased the intracellular calcium level in both $\mathrm{MPP}^{+}$- and $\mathrm{H}_{2} \mathrm{O}_{2}$-treated cells (MPP+ data not given), whereas knockout generated very little change in the intracellular calcium. These findings were also observed in our study when employing the Fluo-4 AM indicator. To determine how GPR4 can modulate the intracellular calcium level, we investigated GPCR-mediated calcium signalling. We found that GPR4 knockout decreases the breakdown of $\mathrm{PIP}_{2}$, which is a critical step in $\mathrm{Ca}^{2+}$ release from the ER to the cytoplasm. Therefore, decreased intracellular $\mathrm{Ca}^{2+}$ may be responsible for GPR4-mediated neuroprotection against $\mathrm{MPP}^{+}$or $\mathrm{H}_{2} \mathrm{O}_{2}$-induced apoptotic cell death. Our study, for the first time, demonstrated that the knockout of GPR4 protects SH-SY5Y cells from both $\mathrm{MPP}^{+}$- and $\mathrm{H}_{2} \mathrm{O}_{2}$-stimulated mitochondrial apoptotic cell death, in association with a decrease in intracellular $\mathrm{Ca}^{2+}$.

In summary, our study suggests that overexpression of GPR4 potentiates neurotoxin-induced mitochondrial oxidative stress, whereas a knockout or pharmacological inhibition of GPR4 improves the neurotoxin-induced, caspase-dependent mitochondrial apoptosis of dopaminergic neuronal cells. This study has also found that GPR4 can increase intracellular $\mathrm{Ca}^{2+}$ through the degradation of $\mathrm{PIP}_{2}$. Further investigation is required to determine how GPR4-mediated calcium signalling can mitigate the neuronal cell death seen in neurodegenerative disorders, including PD.

\section{Materials and Methods}

\subsection{Reagents and Antibodies}

1-methyl-4-phenylpyridinium ion $\mathrm{MPP}^{+}, \mathrm{H}_{2} \mathrm{O}_{2}$, and 3-(3,4-dimehylthiazol-2-yl)-2,5-diphenyltetrazolium bromide (MTT) were obtained from Sigma-Aldrich (St. Louis, MO, USA). 96-well tissue culture plates, along with six-well and $100 \mathrm{~mm}$ culture dishes, were obtained from Nunc Inc. (North Aurora Road, Naperville, IL, USA). Foetal bovine serum (FBS) and Dulbecco's modified Eagle's medium (DMEM/F12) were purchased from Gibco-BRL Technologies (Gaithersburg, MD, USA). RIPA buffer (10X) was purchased from Millipore (Milford, MA, USA). Tween 80 was obtained from Calbiochem (Gibbstown, NJ, USA). All other chemicals utilised in this research were of analytical grade and were purchased, unless otherwise noted, from Sigma-Aldrich.

\subsection{Cell Culture and Transfection}

The human dopaminergic neuroblastoma SH-SY5Y cell line was acquired from the American Type Culture Collection (ATCC; Manassas, VA, USA). SH-SY5Y cells were cultured in DMEM/F12 with or without phenol red and HEPES, supplemented with $100 \mathrm{U} / \mathrm{mL}$ penicillin/streptomycin and $10 \%(\mathrm{v} / \mathrm{v})$ inactivated foetal bovine serum. The SH-SY5Y cells were maintained in a $5 \% \mathrm{CO}_{2}$ and $95 \%$ humidified air incubator at $37^{\circ} \mathrm{C}$ for the time indicated in the experiments. $\mathrm{MPP}^{+}$and $\mathrm{H}_{2} \mathrm{O}_{2}$ were dissolved in three-times distilled water (3DW).

To overexpress and knockout the human GPR4 gene, a GPR4 lentiviral vector (CMV; pLenti-GIII-CMV-C-term-HA) and a GPR4 sgRNA CRISPR/Cas9 lentiviral vector (pLenti-U6-sgRNA-SFFV-Cas9-2A-Puro) were designed, to generate stable GPR4-overexpressing (GPR4-OE) and stable GPR4-knockout (GPR4-KO) SH-SY5Y lines. Briefly, the SH-SY5Y cells were transferred into $60 \mathrm{~mm}$ plates at a density of $5 \times 10^{4}$ cells $/ \mathrm{mL}$ to achieve $\sim 70 \%$ confluence at the time of transfection. The cells were transfected using the Lipofectamine ${ }^{\circledR} 3000$ transfection reagent (ThermoFisher, Langenselbold Germany; \#L3000015), according to the manufacturer's protocol. Both the GPR4-overexpression and knockout-silencing genes were designed to carry puromycin-resistance genes and were produced using the Lentivector Expression System (Applied Biological Materials Inc. (ABM), Canada). Stable single clones were selected following 3-5 weeks of puromycin treatment $(1 \mu \mathrm{g} / \mu \mathrm{L})$. GPR4 overexpression and knockout in the stably infected clones were assessed through RT-PCR and western blotting. A sequence analysis of the GPR4 insert was also employed. 


\subsection{Measurement of Cell Viability}

The cytotoxicity of the MPP ${ }^{+}$and $\mathrm{H}_{2} \mathrm{O}_{2}$-treated SH-SY5Y cells was measured with an MTT assay, involving the reduction of formazan crystals [41]. SH-SY5Y cells $\left(2.2 \times 10^{4} \mathrm{cells} / \mathrm{mL}\right)$ were pre-treated in 24-well plates with NE 52-QQ57 $(100 \mathrm{nM})$ and left in serum-free cell culture media for $1 \mathrm{~h}$; this was followed by stimulation with or without $\mathrm{MPP}^{+}(1 \mathrm{mM})$ or $\mathrm{H}_{2} \mathrm{O}_{2}$ for $24 \mathrm{~h}$. After MPP ${ }^{+}$or $\mathrm{H}_{2} \mathrm{O}_{2}$ stimulation, the medium was replaced with $0.5 \mathrm{mg} / \mathrm{mL}$ MTT solution, before the plates were incubated for $3 \mathrm{~h}$ at $37^{\circ} \mathrm{C}$. The supernatant was carefully removed and the formazan crystals were dissolved in dimethyl sulfoxide (DMSO) by gentle shaking for $10 \mathrm{~min}$. A microplate reader (Molecular device, Sunnyvale, CA, USA) was utilised to measure the absorbance at $550 \mathrm{~nm}$.

\subsection{Total RNA Isolation for RT-PCR}

SH-SY5Y cells $\left(2.2 \times 10^{4}\right.$ cells $\left./ \mathrm{mL}\right)$ were pre-treated in $60 \mathrm{~mm}$ cell culture dishes with NE 52-QQ57 (100 nM), then left in serum-free cell culture media for $1 \mathrm{~h}$, followed by stimulation with or without $\mathrm{MPP}^{+}(1 \mathrm{mM})$ or $\mathrm{H}_{2} \mathrm{O}_{2}$ for $18 \mathrm{~h}$, once again in serum-free media. TRIzol (Invitrogen; Burlington, ON, Canada) was employed to extract the total RNA from the cells. $2.5 \mu \mathrm{g}$ total RNA from each group was reverse-transcribed using a first-strand cDNA synthesis kit (Invitrogen). The following primers were utilised for PCR: GPR4 sense, 5' -CCGTTGTCAAGACCGGGG-3'; GPR4 anti-sense, 5'-TCCTAGGACCCCCAGAAAGCA-3'; Bax sense, 5' -CACCAAGGTGCCGGAACTGA-3'; Bax anti-sense, 5' -AATGCCCATGTCCCCCAATC-3'; Bcl-2 sense, $5^{\prime}$-ACGACTTCTCCCGCCGCTAC-3'; Bcl-2 anti-sense, $5^{\prime}$-CCCAGCCTCCGTTATCCTGG3'; GAPDH sense, 5'-GCAGTGGCAAAGTGGAGATTG-3'; and GAPDH anti-sense, 5' TGCAGGATGCATTGCTGACA-3'. Then, adopting the previously mentioned primers, the cDNA was amplified through PCR [45]. GAPDH was employed as an internal control to evaluate the relative levels of expression of other genes. PCR products were analysed on 1.0-1.2\% agarose gels stained with GelRed (Sigma-Aldrich; St. Louis, MO, USA). The gels were photographed and, utilising ImageJ (NIH) software, the pixel intensity for each band in the photographs was measured and normalised to the band intensity of the GAPDH mRNA, to quantify its relative expression.

\subsection{Immunoblot Analysis}

SH-SY5Y cells $\left(2.2 \times 10^{4}\right.$ cells $\left./ \mathrm{mL}\right)$ were pre-treated in $60 \mathrm{~mm}$ cell culture dishes with NE 52-QQ57 $(100 \mathrm{nM})$ and left in serum-free media for $1 \mathrm{~h}$. They were then stimulated with or without MPP ${ }^{+}$ $(1 \mathrm{mM})$ or $\mathrm{H}_{2} \mathrm{O}_{2}$ for $24 \mathrm{~h}$, again in a serum-free media. Next, the cells were washed two times with PBS and lysed for $10 \mathrm{~min}$ at $4{ }^{\circ} \mathrm{C}$ using an RIPA lysis buffer (with protease and phosphatase inhibitors). Supernatants were collected for further investigation after the cell lysates were centrifuged at $14,000 \mathrm{rpm}$, at $4{ }^{\circ} \mathrm{C}$. The protein concentration of each sample was measured and normalised using a DC Protein Assay kit (Bio-Rad). Equal amounts of proteins (20-30 $\mu \mathrm{g})$ were loaded and separated electrophoretically in 8,10 , and $12 \%$ sodium dodecyl sulphate-polyacrylamide gels; these were then transferred to polyvinylidene difluoride membranes (Millipore; Bedford, MA, USA). The membranes were incubated overnight at $4{ }^{\circ} \mathrm{C}$, with corresponding primary antibodies, GPR4 (1:500) from Novus Biologicals (Centennial, CO, USA), BCL-2 (1:1000), Caspase-3 (1:1000), cleaved Caspase-3 (1:1000), cleaved PARP (1:1000) from Santa Cruz Biotechnology (Santa Cruz, CA, USA), Bax (1:1000) from Cell Signaling Co. (Boston, MA, USA), $\mathrm{PIP}_{2}$ (1:500) from Abcam (Cambridge, United Kingdom), and $\beta$-Actin (1:2000) from Sigma-Aldrich (St. Louis, MO, USA), followed by $1 \mathrm{~h}$ incubation with horseradish peroxidase (HRP)-conjugated secondary antibodies (1:2000; Cell signalling, MA, USA). The blots were visualised using a Biorad-ECL (Bio-Rad Laboratories; Hercules, CA, USA) and photographed. Using ImageJ (NIH) software, the pixel intensity for each band in the photographs was measured and normalised to the band intensity of $\beta$-Actin, to quantify its relative expression. 


\subsection{Detection of Intracellular ROS}

The ROS-sensitive fluorescent dye, $2^{\prime}, 7^{\prime}$-dichlorofluorescein diacetate (DCFDA; Sigma-Aldrich), was utilised to measure the intracellular ROS levels. SH-SY5Y cells $\left(2.2 \times 10^{4}\right.$ cells $\left./ \mathrm{mL}\right)$ were cultured in black 96-well plates in DMEM/F12 without phenol red. Then, 60-70\% confluence cells were stimulated with $\mathrm{H}_{2} \mathrm{O}_{2}(300 \mu \mathrm{M})$ for $1 \mathrm{~h}$ in serum-free media and then washed twice with PBS, followed by a $30 \mathrm{~min}$ incubation with DCFDA $(10 \mu \mathrm{M})$ in PBS. The cells were then rinsed with PBS twice. Finally, $200 \mu \mathrm{L}$ PBS was added, and fluorescence was measured using $485 \mathrm{~nm}$ excitation and $535 \mathrm{~nm}$ in a fluorescence microplate reader (Molecular Device; Sunnyvale, CA, USA).

\subsection{Assessment of Caspase-3 Activity}

Caspase-3 activity was measured using a Colorimetric Caspase-3 Assay Kit (Sigma-Aldrich; St. Louis, MO, USA), as described previously [41]. The reaction mixture (total volume, $200 \mu \mathrm{L}$ ) was distributed in 96-well plates and incubated at $37^{\circ} \mathrm{C}$ for $90 \mathrm{~min}$. Absorbance values were measured at wavelengths of $405 \mathrm{~nm}$ in a Tecan Microplate Reader (Meilen; Zurich, Switzerland).

\subsection{Assessment of Mitochondrial Membrane Potential (MMP)}

A JC-10-based Mitochondrial Membrane Potential Assay Kit (Abcam; Cambridge, United Kingdom) was employed to assess MMP, while a fluorescence microscope was utilised to visualise the JC-10 staining, according to the manufacturer's instructions. In brief, SH-SY5Y cells $\left(2.2 \times 10^{4}\right.$ cells $\left./ \mathrm{mL}\right)$ were cultured in black, 96-well plates for quantification and in 6-well plates for imaging in DMEM/F12 without phenol red. Then, $60-70 \%$ confluence cells were stimulated with $\mathrm{MPP}^{+}$ $(1 \mathrm{mM})$ for $24 \mathrm{~h}$ in serum-free media. The cells were incubated with a JC-10 dye loading solution at $37^{\circ} \mathrm{C}$ for $1 \mathrm{~h}$ and protected from the light. For the 96-well plates, their fluorescence intensities $\left(\lambda_{\mathrm{ex}}=490 / \lambda_{\mathrm{em}}=525 \mathrm{~nm}\right)$ and $\left(\lambda_{\mathrm{ex}}=540 / \lambda_{\mathrm{em}}=590 \mathrm{~nm}\right)$ the red-green fluorescence ratios were measured using a fluorescence microplate reader (Molecular Device; Sunnyvale, CA, USA), while confocal images were acquired with a Nikon Eclipse Ts2-FL diascopic and epi-fluorescence illumination microscope.

\subsection{Detection of Intracellular Calcium}

Intracellular calcium was assessed with a Fluo-4 AM dye (Abcam; Cambridge, United Kingdom) and confocal microscopy, following the manufacturer's instructions. Fluo-4 AM was diluted in DMSO containing $2 \mathrm{mM}$ probenecid and $0.02 \%$ pluronic F-127. In brief, the SH-SY5Y cells $\left(2.2 \times 10^{4} \mathrm{cells} / \mathrm{mL}\right)$ were cultured in black, 96-well plates for quantification and in 6-well plates for imaging in DMEM/F12 without phenol red. Then, 60-70\% confluence cells were stimulated with $\mathrm{H}_{2} \mathrm{O}_{2}(200 \mu \mathrm{M})$ for $2 \mathrm{~h}$ $30 \mathrm{~min}$ in serum-free media. The cells were washed with PBS containing probenecid $(2 \mathrm{mM})$ at room temperature. The cells were incubated with the Fluo-4 AM $(2 \mu \mathrm{M})$ dye loading solution at $37^{\circ} \mathrm{C}$ for $30 \mathrm{~min}$ and protected from light, then washed with PBS containing probenecid $(2 \mathrm{mM})$ at room temperature for $30 \mathrm{~min}$. For the 96-well plates, the fluorescence intensities $\left(\lambda_{\mathrm{ex}}=488 / \lambda_{\mathrm{em}}=515 \mathrm{~nm}\right)$ were measured using a fluorescence microplate reader (Molecular Device; Sunnyvale, CA, USA), and confocal images were acquired with a Nikon Eclipse Ts2-FL diascopic and epi-fluorescence illumination microscope.

\subsection{Statistical Analyses}

Statistical analyses were performed using GraphPad Prism software, version 5 (GraphPad, La Jolla, CA, USA). Data are expressed as means \pm standard error (SEM) of at least three independent experiments. One-way analysis of variance (ANOVA) followed by Tukey's post hoc analysis were performed to determine the significant differences between the groups. $p$-values $<0.05$ were considered statistically significant.

Author Contributions: M.E.H., D.-K.C., and I.-S.K. conceptualized and designed the study; I.-S.K. supervised and corresponded; M.E.H. conducted the experiments and wrote the manuscript; M.E.H. and M.A. analyzed the 
data; M.A. and S.A. have reviewed the literature and proof read the manuscript. All authors have read and agreed to the published version of the manuscript.

Funding: This study was supported by the Basic Science Research Program through the National Research Foundation of Korea (NRF) funded by the Ministry of Science and ICT (NRF-2018R1C1B6005129). All authors have read and agree to the published version of the manuscript.

Acknowledgments: Authors especially like to thank Md Jakaria for his support during the whole research.

Conflicts of Interest: The authors declare no conflict of interest.

$\begin{array}{ll}\text { Abbreviations } \\ \text { MPTP } & \text { 1-Methyl-4-Phenyl-1,2,3,6-Tetrahydropyridine } \\ \text { MPP }^{+} & \text {1-Methyl-4-Phenylpyridinium Ion } \\ \text { MTT } & \text { 3-(3,4-Dimehylthiazol-2-Yl)-2,5-Diphenyl-Tetrazolium Bromide } \\ \text { DCF-DA } & \text { 7'-Dichlorofluorescein Diacetate } \\ \text { DMEM } & \text { Dulbecco's Modified Eagle's Medium } \\ \text { ER } & \text { Endoplasmic Reticulum } \\ \text { FBS } & \text { Fetal Bovine Serum } \\ \text { HUVEC } & \text { Human Umbilical Vein Endothelial Cells } \\ \text { MMP } & \text { Mitochondrial Membrane Potential } \\ \text { Mptp } & \text { Mitochondrial Permeability Transition Pore } \\ \text { PIP2 } & \text { Phosphatidylinositol Biphosphate } \\ \text { PARP } & \text { Poly (ADP-Ribose) Polymerase } \\ \text { SN } & \text { Substantia Nigra } \\ \text { TDAG8 } & \text { T-Cell Death-Associated Gene 8 } \\ \text { OGR1 } & \text { The Ovarian Cancer G Protein-Coupled Receptor 1 }\end{array}$

\section{References}

1. Zhang, Q.; Hu, C.; Huang, J.; Liu, W.; Lai, W.; Leng, F.; Tang, Q.; Liu, Y.; Wang, Q.; Zhou, M.; et al. ROCK1 induces dopaminergic nerve cell apoptosis via the activation of Drp1-mediated aberrant mitochondrial fission in Parkinson's disease. Exp. Mol. Med. 2019, 51, 1-13. [CrossRef] [PubMed]

2. Henchcliffe, C.; Beal, M.F. Mitochondrial biology and oxidative stress in Parkinson disease pathogenesis. Nat. Clin. Pract. Neurol. 2008, 4, 600-609. [CrossRef]

3. Mattson, M.P. Apoptosis in neurodegenerative disorders. Nat. Rev. Mol. Cell Biol. 2000, 1, 120-130. [CrossRef]

4. Ly, J.D.; Grubb, D.R.; Lawen, A.J.A. The mitochondrial membrane potential $(\Delta \psi \mathrm{m})$ in apoptosis; an update. Apoptosis 2003, 8, 115-128. [PubMed]

5. Prenek, L.; Boldizsár, F.; Kugyelka, R.; Ugor, E.; Berta, G.; Németh, P.; Berki, T. The regulation of the mitochondrial apoptotic pathway by glucocorticoid receptor in collaboration with Bcl-2 family proteins in developing T cells. Apoptosis 2017, 22, 239-253. [CrossRef] [PubMed]

6. Gerace, E.; Masi, A.; Resta, F.; Felici, R.; Landucci, E.; Mello, T.; Pellegrini-Giampietro, D.; Mannaioni, G.; Moroni, F. PARP-1 activation causes neuronal death in the hippocampal CA1 region by increasing the expression of $\mathrm{Ca}^{2+}$-permeable AMPA receptors. Neurobiol. Dis. 2014, 70, 43-52. [CrossRef] [PubMed]

7. Chaitanya, G.V.; Alexander, J.S.; Babu, P.P. PARP-1 cleavage fragments: Signatures of cell-death proteases in neurodegeneration. Cell Commun. Signal. 2010, 8, 31. [CrossRef]

8. More, S.V.; Choi, D.-K. Atractylenolide-I Protects Human SH-SY5Y Cells from 1-Methyl-4-PhenylpyridiniumInduced Apoptotic Cell Death. Int. J. Mol. Sci. 2017, 18, 1012. [CrossRef]

9. Kirichok, Y.; Krapivinsky, G.; Clapham, D.E. The mitochondrial calcium uniporter is a highly selective ion channel. Nat. Cell Biol. 2004, 427, 360-364. [CrossRef]

10. Surmeier, D.J.; Guzman, J.N.; Sanchez-Pandila, J.; Schumacker, P.T. The role of calcium and mitochondrial oxidant stress in the loss of substantia nigra pars compacta dopaminergic neurons in Parkinson's disease. Neuroscience 2011, 198, 221-231.

11. Gunter, T.E.; Gunter, K.K. Uptake of Calcium by Mitochondria: Transport and Possible Function. IUBMB Life 2001, 52, 197-204. [CrossRef] 
12. Haupt, S.; Raghu, D.; Haupt, Y. p53 Calls upon CIA (Calcium Induced Apoptosis) to Counter Stress. Front. Oncol. 2015, 5, 57. [CrossRef] [PubMed]

13. Mosharov, E.V.; Larsen, K.E.; Kanter, E.; Phillips, K.A.; Wilson, K.; Schmitz, Y.; Krantz, D.E.; Kobayashi, K.; Edwards, R.H.; Sulzer, D. Interplay between Cytosolic Dopamine, Calcium, and $\alpha$-Synuclein Causes Selective Death of Substantia Nigra Neurons. Neuron 2009, 62, 218-229. [CrossRef] [PubMed]

14. Sheehan, J.P.; Swerdlow, R.H.; Parker, W.D.; Miller, S.W.; Davis, R.E.; Tuttle, J.B. Altered calcium homeostasis in cells transformed by mitochondria from individuals with Parkinson's disease. J. Neurochem. 1997, 68, 1221-1233. [CrossRef] [PubMed]

15. Singer, T.P.; Ramsay, R.R. Mechanism of the neurotoxicity of MPTP. FEBS Lett. 1990, 274, 1-8. [CrossRef]

16. Przedborski, S.; Jackson-Lewis, V. Mechanisms of MPTP toxicity. Mov. Disord. 1998, 13, 35-38.

17. Dumont, A.; Hehner, S.P.; Hofmann, T.G.; Ueffing, M.; Dröge, W.; Schmitz, M.L. Hydrogen peroxide-induced apoptosis is CD95-independent, requires the release of mitochondria-derived reactive oxygen species and the activation of NF-кB. Oncogene 1999, 18, 747-757. [CrossRef]

18. Wang, C.; Youle, R.J. The role of mitochondria in apoptosis. Annu. Rev. Genet. 2009, 43, 95-118. [CrossRef]

19. Uğuz, A.C.; Öz, A.; Nazıroğlu, M. Curcumin inhibits apoptosis by regulating intracellular calcium release, reactive oxygen species and mitochondrial depolarization levels in SH-SY5Y neuronal cells. J. Recept. Signal Transduct. 2016, 36, 395-401. [CrossRef]

20. Knaryan, V.H.; Samantaray, S.; Park, S.; Azuma, M.; Inoue, J.; Banik, N.L.; Sookyoung, P. SNJ-1945, a calpain inhibitor, protects SH-SY5Y cells against $\mathrm{MPP}^{+}$and rotenone. J. Neurochem. 2014, 130, 280-290. [CrossRef]

21. Meyer, T.N.; Gloy, J.; Hug, M.J.; Greger, R.; Schollmeyer, P.; Pavenstädt, H. Hydrogen peroxide increases the intracellular calcium activity in rat mesangial cells in primary culture. Kidney Int. 1996, 49, 388-395. [CrossRef] [PubMed]

22. Ludwig, M.-G.; Vanek, M.; Guerini, D.; Gasser, J.A.; Jones, C.E.; Junker, U.; Hofstetter, H.; Wolf, R.M.; Seuwen, K. Proton-sensing G-protein-coupled receptors. Nat. Cell Biol. 2003, 425, 93-98. [CrossRef] [PubMed]

23. Ishii, S.; Kihara, Y.; Shimizu, T. Identification of T Cell Death-associated Gene 8 (TDAG8) as a Novel Acid Sensing G-protein-coupled Receptor. J. Biol. Chem. 2005, 280, 9083-9087. [CrossRef] [PubMed]

24. Justus, C.R.; Dong, L.; Yang, L.V. Acidic tumor microenvironment and pH-sensing G protein-coupled receptors. Front. Physiol. 2013, 4, 354. [CrossRef]

25. Hosford, P.; Mosienko, V.; Kishi, K.; Jurisic, G.; Seuwen, K.; Kinzel, B.; Ludwig, M.; Wells, J.; Christie, I.; Koolen, L.; et al. CNS distribution, signalling properties and central effects of G-protein coupled receptor 4. Neuropharmacology 2018, 138, 381-392. [CrossRef]

26. Dong, B.; Zhang, X.; Fan, Y.; Cao, S.; Zhang, Y. Acidosis promotes cell apoptosis through the G protein-coupled receptor 4/CCAAT/enhancer-binding protein homologous protein pathway. Oncol. Lett. 2018, 16, 6735-6741. [CrossRef]

27. Krewson, E.A.; Sanderlin, E.J.; Marie, M.A.; Akhtar, S.N.; Velcicky, J.; Loetscher, P.; Yang, L.V. The Proton-Sensing GPR4 Receptor Regulates Paracellular Gap Formation and Permeability of Vascular Endothelial Cells. iScience 2020, 23, 100848. [CrossRef]

28. Dong, B.; Zhou, H.; Han, C.; Yao, J.; Xu, L.; Zhang, M.; Fu, Y.; Xia, Q. Ischemia/Reperfusion-Induced CHOP Expression Promotes Apoptosis and Impairs Renal Function Recovery: The Role of Acidosis and GPR4. PLoS ONE 2014, 9, e110944. [CrossRef]

29. Mortadza, S.S.; Sim, J.A.; Stacey, M.; Jiang, L.-H. Signalling mechanisms mediating $\mathrm{Zn}^{2+}$-induced TRPM2 channel activation and cell death in microglial cells. Sci. Rep. 2017, 7, srep45032. [CrossRef]

30. Gross, A.; McDonnell, J.M.; Korsmeyer, S.J. BCL-2 family members and the mitochondria in apoptosis. Genes Dev. 1999, 13, 1899-1911. [CrossRef]

31. Hartmann, A.; Hunot, S.; Michel, P.P.; Muriel, M.-P.; Vyas, S.; Faucheux, B.A.; Mouatt-Prigent, A.; Turmel, H.; Srinivasan, A.; Ruberg, M.; et al. Caspase-3: A vulnerability factor and final effector in apoptotic death of dopaminergic neurons in Parkinson's disease. Proc. Natl. Acad. Sci. USA 2000, 97, 2875-2880. [CrossRef] [PubMed]

32. Jung, S.; Chung, Y.; Lee, Y.; Lee, Y.; Cho, J.W.; Shin, E.-J.; Kim, H.-C.; Oh, Y.J. Buffering of cytosolic calcium plays a neuroprotective role by preserving the autophagy-lysosome pathway during $\mathrm{MPP}^{+}$-induced neuronal death. Cell Death Discov. 2019, 5, 130. [CrossRef] [PubMed] 
33. Kruman, I.; Guo, Q.; Mattson, M.P. Calcium and reactive oxygen species mediate staurosporine-induced mitochondrial dysfunction and apoptosis in PC12 cells. J. Neurosci. Res. 1998, 51, 293-308. [CrossRef]

34. Lynch, K.; Fernández, G.; Pappalardo, A.; Peluso, J.J. Basic Fibroblast Growth Factor Inhibits Apoptosis of Spontaneously Immortalized Granulosa Cells by Regulating Intracellular Free Calcium Levels through a Protein Kinase C $\delta$-Dependent Pathway. Endocrinol. 2000, 141, 4209-4217. [CrossRef]

35. Kiselyov, K.; Shin, D.M.; Muallem, S. Signalling specificity in GPCR-dependent $\mathrm{Ca}^{2+}$ signalling. Cell. Signal. 2003, 15, 243-253. [CrossRef]

36. Frick, K.K.; Krieger, N.S.; Nehrke, K.; Bushinsky, A.D. Metabolic Acidosis Increases Intracellular Calcium in Bone Cells Through Activation of the Proton Receptor OGR1. J. Bone Miner. Res. 2009, 24, 305-313. [CrossRef] [PubMed]

37. Tobo, M.; Tomura, H.; Mogi, C.; Wang, J.-Q.; Liu, J.-P.; Komachi, M.; Damirin, A.; Kimura, T.; Murata, N.; Kurose, H.; et al. Previously postulated "ligand-independent" signaling of GPR4 is mediated through proton-sensing mechanisms. Cell. Signal. 2007, 19, 1745-1753. [CrossRef] [PubMed]

38. Kumar, N.N.; Velic, A.; Soliz, J.; Shi, Y.; Li, K.; Wang, S.; Weaver, J.L.; Sen, J.; Abbott, S.B.; Lazarenko, R.M.; et al. Regulation of breathing by $\mathrm{CO}_{2}$ requires the proton-activated receptor GPR4 in retrotrapezoid nucleus neurons. Science 2015, 348, 1255-1260. [CrossRef]

39. Wang, X.; Wang, W.; Li, L.; Perry, G.; Lee, H.-G.; Zhu, X. Oxidative stress and mitochondrial dysfunction in Alzheimer's disease. Biochim. Biophys. Acta (BBA) Mol. Basis Dis. 2014, 1842, 1240-1247. [CrossRef]

40. Fall, C.P.; Bennett, J.P. Characterization and time course of $\mathrm{MPP}^{+}$-induced apoptosis in human SH-SY5Y neuroblastoma cells. J. Neurosci. Res. 1999, 55, 620-628. [CrossRef]

41. Kim, I.-S.; Ganesan, P.; Choi, D.-K. Cx43 Mediates Resistance against MPP ${ }^{+}$-Induced Apoptosis in SH-SY5Y Neuroblastoma Cells via Modulating the Mitochondrial Apoptosis Pathway. Int. J. Mol. Sci. 2016, 17, 1819. [CrossRef] [PubMed]

42. Dauer, W.; Przedborski, S.J.N. Parkinson's disease: Mechanisms and models. Neuron 2003, 39, 889-909.

43. Singh, A.; Verma, P.; Balaji, G.; Samantaray, S.; Mohanakumar, K.P. Nimodipine, an L-type calcium channel blocker attenuates mitochondrial dysfunctions to protect against 1-methyl-4-phenyl-1,2,3,6tetrahydropyridine-induced Parkinsonism in mice. Neurochem. Int. 2016, 99, 221-232. [CrossRef] [PubMed]

44. Liu, J.-P.; Nakakura, T.; Tomura, H.; Tobo, M.; Mogi, C.; Wang, J.-Q.; He, X.-D.; Takano, M.; Damirin, A.; Komachi, M.; et al. Each one of certain histidine residues in G-protein-coupled receptor GPR4 is critical for extracellular proton-induced stimulation of multiple G-protein-signaling pathways. Pharmacol. Res. 2010, 61, 499-505. [CrossRef]

45. Karthivashan, G.; Park, S.-Y.; Kweon, M.-H.; Kim, J.; Haque, E.; Cho, D.-Y.; Kim, I.-S.; Cho, E.-A.; Ganesan, P.; Choi, D.-K. Ameliorative potential of desalted Salicornia europaea L. extract in multifaceted Alzheimer's-like scopolamine-induced amnesic mice model. Sci. Rep. 2018, 8, 7174. [CrossRef] [PubMed] 